\title{
Can I Sustain My Happiness? A Review, Critique and Research Agenda for Economics of Happiness
}

\author{
Mansi Jain ${ }^{1}\left(0\right.$, Gagan Deep Sharma ${ }^{1, *}\left(\mathbb{C}\right.$ and Mandeep Mahendru ${ }^{2}$ \\ 1 University School of Management Studies, Guru Gobind Singh Indraprastha University, New Delhi 110078, \\ India; guptamansi007@gmail.com \\ 2 State Bank Institute of Credit and Risk Management, Gurugram 122015, India; mandip129@gmail.com \\ * Correspondence: angrishgagan@gmail.com; Tel.: +91-85274-00113
}

Received: 21 October 2019; Accepted: 10 November 2019; Published: 13 November 2019

\begin{abstract}
Human beings want to live in a state of happiness and prosperity, but happiness is important not just for the well-being of individuals but for the well-being of society. To ensure the maximization of happiness, it is necessary to consider more than just money, and rather include the right understanding of happiness at the individual level, the family level, the society level, and the environmental (nature) level. This paper contributes to the existing body of knowledge by consolidating the findings of the literature; grouping those into major themes and sub-themes; describing the mechanisms based on the empirical papers by highlighting the independent, dependent, control, and moderating variables, to study the causal relationships between variables under study; proposing an agenda for future research; and informing the policymakers about decisions influencing the human happiness level through legislative rules and regulations. Our results suggest prioritizing the conceptualization of happiness while computing the happiness level at the individual or collective levels. Furthermore, the study recommends governments to establish the conditions enabling individuals to report happiness independently from the political pressure to answer strategically for impressive happiness level figures at the macro level.
\end{abstract}

Keywords: happiness; subjective well-being; life satisfaction; income inequality; income-happiness paradox; socio-economic factors

\section{Introduction}

Attaining happiness is the ultimate goal of human beings [1,2]. All human activities-economic, political, social, or otherwise-are directed towards attaining this goal [3]. Aristotle (350 B.C.) maintains that the non-attainment of this goal renews the motivation to think beyond the material for humans to be happy [4].

As part of the general movement, along with the foundation of behavioral economics, a new line of research, namely, happiness economics, has emerged. Happiness economics relies on the more extensive concept of utility and welfare, including the interdependent utility function, procedural utility, and the interaction between rational and non-rational influences in determining economic behavior [5]. The study of happiness and subjective well-being is growing to incorporate publications across disciplines, from psychology to economics and sociology [6]. Research on happiness has also grown in fields such as philosophy, psychiatry, cognitive neuroscience, and gerontology, signifying a broader academic reporting on how people's feelings and expectations change with different life experiences [7].

The economics of happiness has increasingly been gathering the attention of researchers and policymakers in the field of economics and business. This concept has intrigued scholars ever since the question of whether happiness is relative or absolute was highlighted [8]. Hsee et al. [8] maintained that 
such an argument has social implications, where happiness is relative to money and to the acquisition of an item but can be relative or absolute with consumption of the item.

Beginning with the early 1970s, Richard Easterlin was the first modern economist to revisit the concept of happiness. Easterlin reported an increase in happiness in the United States from 1946 to 1956-1967, with a decline towards the 1970s, and then with minimal change over the next 24 years [9]. Decades later, Easterlin [10] implemented a survey across different countries and found that, over short periods, economic growth and happiness were positively correlated, while in the long run, trends in happiness and income were not related. Another striking contradiction in the paper was that life satisfaction in China has not heightened regardless of the increase in real GDP per capita from a lower level.

All this debate triggers us to critically review the existing literature associated with the field of economics of happiness from the lens of an individual (understanding self), family (human-human relationships), society (human-system relationship) and the environment (human-nature relationship). There has been little research incorporating all these issues, and on recognizing happiness from a holistic viewpoint. Hence, this urges us to identify the gaps and to lay down the agenda for future researchers in this upcoming field.

Figure 1 presents the framework of this paper, divided into seven major themes, with the number of papers studying each theme. Papers that study more than one theme/sub-theme are included in all related themes/sub-themes.

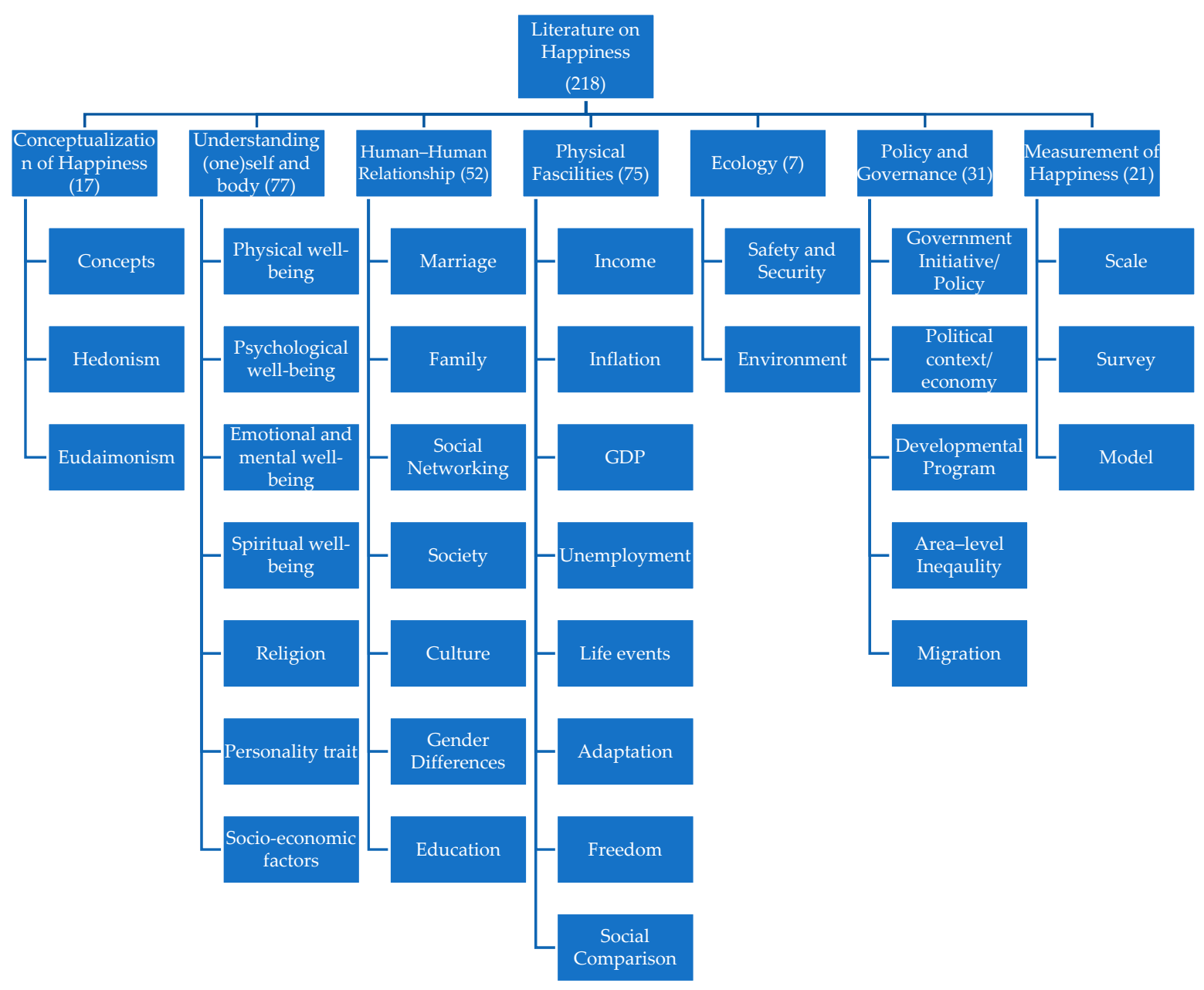

Figure 1. The organizing framework for studying happiness. 
This paper contributes to the existing body of knowledge by consolidating the findings of the literature; grouping those into major themes and sub-themes; describing the mechanisms based on the empirical papers by highlighting the independent, dependent, control, and moderating variables considered for evaluating the causal relationships between the variables under study; proposing an agenda for future research in the field; and informing the policymakers about decisions influencing the human happiness level through legislative rules and regulations.

The rest of the paper is organized as follows. Section 2 discusses the concept of happiness and presents the review methodology; Section 3 presents the findings, segregated into descriptive findings and thematic discussion; Section 4 highlights the gaps in existing literature; Section 5 presents the directions for future research and the last section presents the conclusions.

\section{Economics of Happiness-Concepts}

Philosophers and economists, ranging from Aristotle to Bentham, Mill and Smith, integrated the quest for happiness into their work. With more rigorous efforts of the economists, more frugal explanations of welfare took hold. The advent of behavioral economics led to the foundation of new lines of research. The economics of happiness relies on a more extensive viewpoint on utility and welfare, including economic behavior [5]. From the perspective of utilitarian philosophy, happiness research refers to well-being as a discrete and subjective state of individuals. In this sense, maximizing well-being can be based on ethical judgment according to the research on happiness [11]. For instance, Layard [12] identifies positive well-being with "a good feeling" and negative well-being with "a bad feeling".

On the other hand, the "eudemonic" approach to well-being can be drawn from the work of Aristotle and his idea on the kind of life one can lead, opposing the subjective approach [13]. Aristotle suggests that wealth and income are general-purpose means for having more freedom to lead the kind of life one desires, and for the same reason, economic growth is not the end and development must be concerned with enhancing the life and freedom of an individual. Growing freedom not only makes life more productive and unrestrained but also enables us to be fuller social persons, interacting and influencing the world we live in [14]. Hence, according to Sen [14], well-being refers to what people are able to be and do, understanding the multiple objective needs, which includes not only the basic physical needs, but also the fundamental needs to advance while fulfilling personal goals with freedom and creativity at work, education and building healthy family and social relationships, and other pursuits [11].

Subjective well-being is the scientific term for happiness, as concisely elaborated by Diener [15]. It refers to a relatively stable state, such as life satisfaction and emotional experiences [16]. Hence, subjective well-being comprises of three main components, namely, the existence of positive emotions or high levels of positive effects, absence of negative emotions or low levels of negative effects, and life satisfaction [6]. The presence of positive effects and absence of negative effects actualize the affect balance and are affected by daily events (e.g., eating tasty food, facing traffic) while life satisfaction refers to a long-term cognitive valuation of one's own life [17].

Economic well-being is indicated by one's economic self-sufficiency, as a result of an individual's economic outcome (e.g., income), financial status (e.g., assets and debts) and future choice concerning the economic situation [18]. Amartya Sen has suggested the use of income and commodities as the material basis of our well-being [14]. The economics in Kautilya's Arthasastra (the edited, rearranged, translated and introduced version produced by L. N. Rangarajan centuries later) is defined as "something like instructions on material prosperity" [19]. Economic well-being refers to present and future financial security. Present financial security implies the ability to meet basic needs and to control routine finances, along with the ability to make economic choices that provide a sense of satisfaction and security, and sound financial and employment status. Future financial security refers to the capacity to surpass financial shocks and maintain enough income throughout life [20]. 


\section{Review Methodology}

This paper discusses the themes explored by extant literature across the countries. The methodological approach of this paper involves the following steps:

1. Analyzing the papers previously published

2. Categorizing them according to different parameters;

3. Presenting a summary of their contribution; and

4. Providing the future scope for further research.

The methodology of the review was inspired by Denyer, Tranfield, and Smart [21], Nofal, Nicolaou, Symeonidou, and Shane [22], Talan and Sharma [23] and Bansal, Garg, and Sharma [24], involving a review protocol to enable transparency and replicability by providing an explicit description of each step taken during the entire process of review, specifying the research questions addressed, the search strategy, and the criteria of exclusion and inclusion of the studies in the review [25]. This paper is an extension of a developing paper [26] that highlights the research gaps and scope for future research. The methodology involves three stages—planning, conducting, and reporting the review.

\subsection{Planning and conducting the review}

The Web of Science database was accessed to search for relevant literature. As a multidisciplinary database, Web of Science (WoS) is easier for access to literature of finance, economics, technology, and other fields and enables the procurement of the most recent and significant research. Also, compared to Scopus, WoS has reliable coverage that goes back to 1990 [27]. Only English-based documents in the form of an article, review, or editorial were considered for our research. Pure technology-based papers were excluded from the search. Papers based on various other research areas, namely, rehabilitation, biomedical, social sciences, communication, dentistry oral surgery medicine, substance abuse, urology nephrology, substance abuse, pediatrics, nutrition dietetics, and genetics heredity were excluded from our research. We excluded the papers where happiness is just a medium and not the ultimate goal of achievement, for example, papers suggesting an orientation to happiness.

The search was conducted in 2018 using the Boolean criteria wherein the term "happiness" is used synonymously with subjective well-being (SWB), life satisfaction, well-being, and welfare as evident in the previous works [28-32]. The search query resulted in an initial list of 411 papers out of which 218 were finally selected, as depicted in Figure 2. 


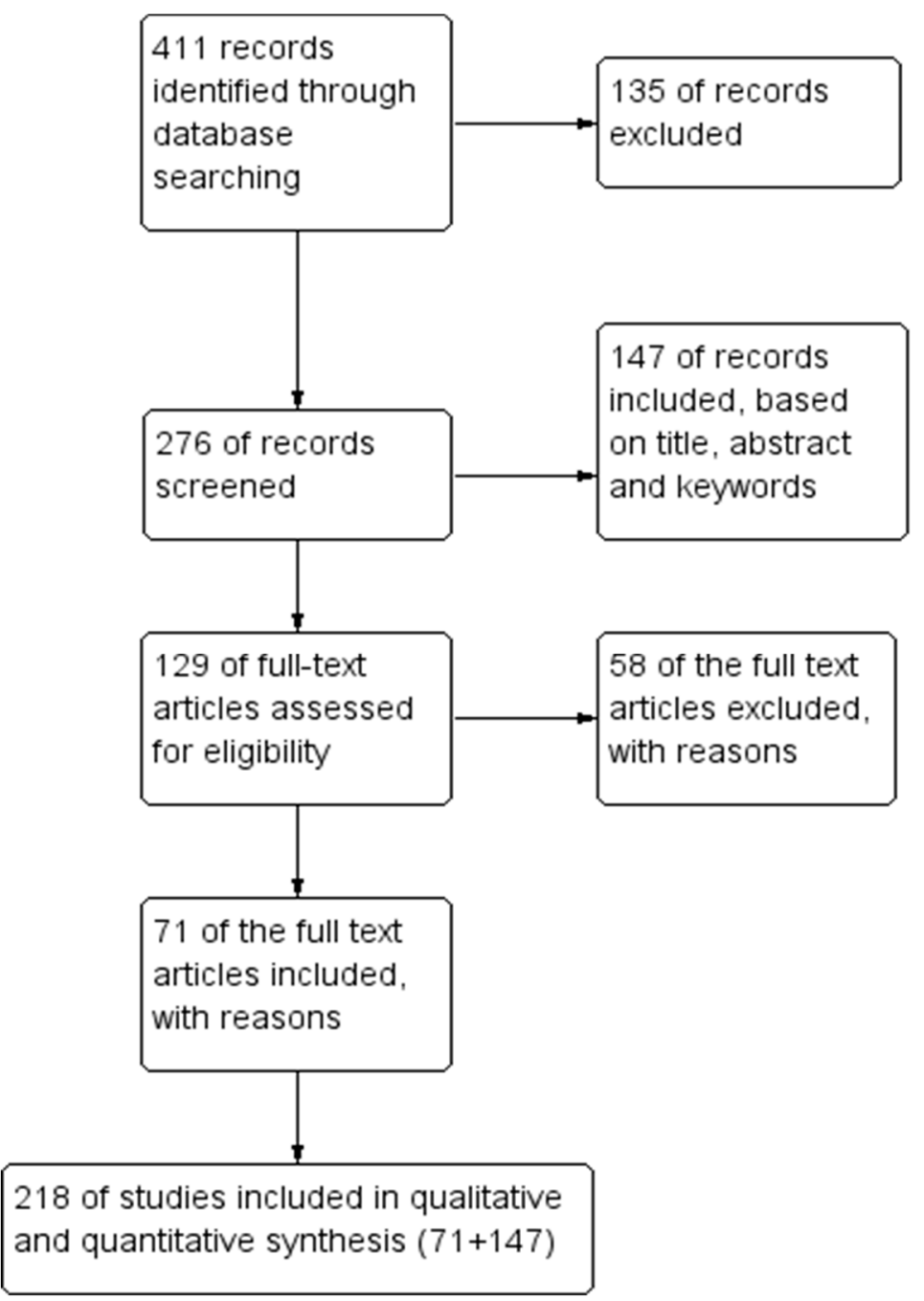

Figure 2. Flow diagram (based on Preferred Reporting Items for Systematic Reviews and Meta Analyses (PRISMA) guidelines).

\subsection{Selection of articles}

Initially, each paper was assessed based on the field of study, leading to the exclusion of 135 papers. This process brought us to 276 papers, which were evaluated on the basis of their abstract and keywords. One hundred and forty-seven records were shortlisted at this stage, while 129 papers were kept in the doubtful category. Out of these 129 papers, we excluded the ones conducting happiness-based surveys of students in preschool and included the ones where the study was conducted on students in higher secondary schools and beyond. This further led to the exclusion of 58 papers and the shortlisting of 71 papers. Eventually, 218 papers are shortlisted. With a thorough analysis, we then categorized the issues raised by the authors and their contributions made in this field.

\subsection{Reporting the Review}

For the review of the literature, a systematic review approach was endeavored, which involved a thorough analysis of the existing literature indexed in the Web of Science (WoS) database, with an intent to outline the critical topics of research in this field, followed by the identification of gaps in the literature. 


\section{Results}

\subsection{Descriptive Findings}

The papers under study were analyzed in terms of year-wise publications defining the number of publications per year and year-wise citations outlining the number of papers cited each year (Figure 3).

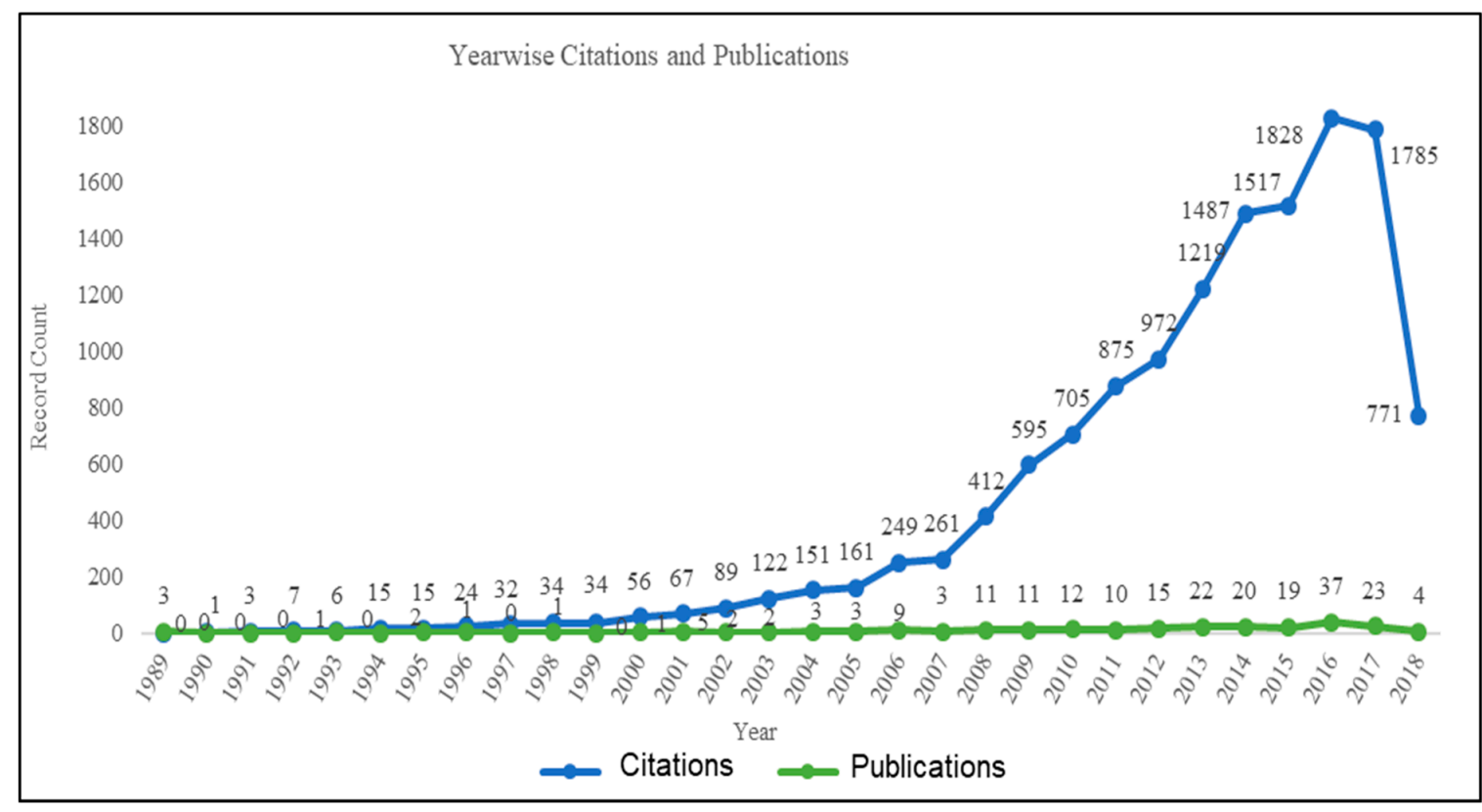

Figure 3. Year-wise citations and publications.

Out of the 218 papers understudied, the maximum articles were published in the year 2016 (37), followed by the year 2017 (23), and 2013 (22). The origin of research in the economics of happiness dates back to 1989 when three papers were published.

\subsection{Thematic Discussion}

Based on the categorization, this section presents the themes and the sub-themes of each of the paper studied (Tables 1 and 2), followed by the mechanism table that discusses the various empirical papers, highlighting the top most independent, mediating, and control variables. The results can be useful for the policymakers to make practical decisions in terms of employment, health, education, work engagement, social and economic growth that directly or indirectly affect happiness levels, by drawing legislative reforms and institutional changes. 
Table 1. Themes and sub-themes.

\begin{tabular}{|c|c|c|}
\hline S.No. & Themes & Sub-Themes \\
\hline 1. & Conceptualization of Happiness & $\begin{array}{ll}\text { A. } & \text { Concepts } \\
\text { B. } & \text { Hedonism } \\
\text { C. } & \text { Eudaimonism }\end{array}$ \\
\hline 2. & Understanding Oneself and Body & $\begin{array}{ll}\text { A. } & \text { Physical Well-Being } \\
\text { B. } & \text { Psychological Well-Being } \\
\text { C. } & \text { Emotional and Mental Well-Being } \\
\text { D. } & \text { Spiritual Well-Being } \\
\text { E. } & \text { Religion } \\
\text { F. } & \text { Personality Trait } \\
\text { G. } & \text { Socio-Economic Factors }\end{array}$ \\
\hline 3. & Human-Human relations & $\begin{array}{ll}\text { A. } & \text { Marriage } \\
\text { B. } & \text { Family } \\
\text { C. } & \text { Social Networking } \\
\text { D. } & \text { Society } \\
\text { E. } & \text { Culture } \\
\text { F. } & \text { Gender Differences } \\
\text { G. } & \text { Education } \\
\end{array}$ \\
\hline 4. & Physical Facilities & $\begin{array}{ll}\text { A. } & \text { Income } \\
\text { B. } & \text { Inflation } \\
\text { C. } & \text { GDP } \\
\text { D. } & \text { Unemployment } \\
\text { E. } & \text { Life Events } \\
\text { F. } & \text { Adaptation } \\
\text { G. } & \text { Freedom } \\
\text { H. } & \text { Social Comparison } \\
\end{array}$ \\
\hline 5. & Ecology & $\begin{array}{ll}\text { A. } & \text { Safety and Security } \\
\text { B. } & \text { Environment }\end{array}$ \\
\hline 6. & Policy and Governance & $\begin{array}{ll}\text { A. } & \text { Government Initiative/Policy } \\
\text { B. } & \text { Political Context/Economy } \\
\text { C. } & \text { Developmental Program } \\
\text { D. } & \text { Area-Level Inequality } \\
\text { E. } & \text { Migration }\end{array}$ \\
\hline 7. & Measurement of Happiness & $\begin{array}{ll}\text { A. } & \text { Scale } \\
\text { B. } & \text { Survey } \\
\text { C. } & \text { Model }\end{array}$ \\
\hline
\end{tabular}


Table 2. Major themes of research in the economics of happiness.

\begin{tabular}{|c|c|c|}
\hline S. No. & Themes & References \\
\hline 1. & Conceptualization of Happiness & $\begin{array}{l}\text { Vermunt [33]; Ryan and Deci [34]; Sousa [35]; Martin [36]; } \\
\text { Feldman [37]; Svensson [38]; Caunt, Franklin, Brodaty, and } \\
\text { Brodaty [39]; Straume and Vitterso [40]; Badhwar [41]; Lepp [42] }\end{array}$ \\
\hline 2. & Understanding Oneself and Body & $\begin{array}{l}\text { Ryff [43]; Vermunt [33]; Hosen [44]; Bishop et al. [45]; Miquelon } \\
\text { and Vallerand [46]; Di Tella and MacCulloch [47]; Selim [48]; } \\
\text { Siahpush, Spittal, and Singh [49]; Linley, Maltby, Wood, } \\
\text { Osborne, and Hurling [50]; Simsek [51]; Spiers and Walker [52]; } \\
\text { Xiao, Tang, and Shim [53]; Raibley [54]; Edouard and Duhaime } \\
\text { [55]; Power [56]; Schutz et al. [57]; Ramanathan et al. [58]; } \\
\text { Backman [28]; Mujcic and Oswald [59]; Pandya [60] }\end{array}$ \\
\hline 3. & Human-Human Relationships & $\begin{array}{l}\text { Ruvolo [61]; Stacy J. Rogers and DeBoer [62]; Roysamb et al. } \\
\text { [63]; Di Tella and MacCulloch [47]; Benjamin, Heffetz, Kimball, } \\
\text { and Szembrot [64]; Jones [65]; Schnitzlein and Wunder [66]; } \\
\text { Heizomi, Allahverdipour, Jafarabadi, and Safaian [67]; Bartels } \\
\text { [68]; Kelley and Evans [69] }\end{array}$ \\
\hline 4. & Physical Facilities & $\begin{array}{l}\text { Stacy J. Rogers and DeBoer [62]; Biswas-Diener and Diener [70]; } \\
\text { Leigh and Wolfers [71]; Clark, Frijters, and Shields [72]; Di Tella } \\
\text { and MacCulloch [47]; Mahadea and Rawat [73]; Selim [48]; Hsee, } \\
\text { Yang, Li, and Shen [8]; Xiao at al. [53]; Boyce, Brown, and Moore } \\
\text { [74]; Delhey [75]; Easterlin, McVey, Switek, Sawangfa, and } \\
\text { Zweig [76]; Delhey and Kohler [77]; Oishi, Kesebir, and Diener } \\
\text { [78]; Blanchflower, Bell, Montagnoli, and Moro [79]; Strizovic } \\
\text { and Mratinkovic [80]; Graham, Zhou, and Zhang [81]; } \\
\text { Poormahmood, Moayedi, and Alizadeh [82]; Joo and Lee [83] }\end{array}$ \\
\hline 5. & Ecology & $\begin{array}{l}\text { Roysamb et al. [63]; ; Di Tella and MacCulloch [47]; Benjamin et } \\
\text { al. [64]; Potapov, Shafranskaya, and Bozhya-Volya [84]; Ambrey } \\
\text { and Daniels [85] }\end{array}$ \\
\hline 6. & Policy and Governance & $\begin{array}{l}\text { Radcliff [86]; Gundelach and Kreiner [87]; Di Tella and } \\
\text { MacCulloch [47]; Clapham [88]; Kroll [89]; Meier and } \\
\text { Chakrabarti [90]; Strotmann and Volkert [91]; Alessandrini and } \\
\text { Jivraj [92]; Oishi et al. [93] }\end{array}$ \\
\hline 8. & Measurement of Happiness & $\begin{array}{l}\text { Lewis and Joseph [94]; Hills and Argyle [95]; Joseph, Linley, } \\
\text { Harwood, Lewis, and McCollam [96]; Cox [97]; L. A. Weiss et al. } \\
\text { [98]; Santos [99]; Benjamin et al. [64]; Roberts, Tsang, and } \\
\text { Manolis [100]; Choi and Jang [101]; Joshanloo [102] }\end{array}$ \\
\hline
\end{tabular}

\subsubsection{Conceptualization of Happiness}

Aristotle's concepts of eudaimonia and hedonic enjoyment constitute two distant philosophical conceptions of happiness [4]. Hedonism [103] defines well-being as pleasure attainment or pain avoidance while eudaimonia [104] refers to the actualizations of human potential, signifying the belief that well-being constitutes the fulfillment or realization of one's true nature. Hedonomics is an emerging branch of economics where economics focuses on maximizing wealth with limited resources, which refers to maximizing happiness with limited wealth. Additionally, it is complementary to conventional economics in defining the idea of happiness. The economic analysis of happiness is behaviorist and external-choice focused, and hedonomics further argues that happiness can be enhanced by augmenting the association between external outcomes, preferences and experiences. It examines the degree to which the external outcomes affect happiness, and when and why the choices fail to enhance the happiness level [105].

People generally value happiness [30], and based on its value, the pursuit of happiness is recognized as an "inalienable right" in the US Declaration of Independence. Thus, it is reasonable to expect that people who value happiness report higher levels of happiness. However, Mauss et al. [106] found that valuing happiness is self-defeating, implying that valuing happiness increases the chance of being more disappointed. Contradictory to this, Luhmann et al. [107] employed the 
Valuing Happiness Scale and opined that valuing happiness may not have a negative impact on one's well-being. Raibley [54] aspired to define the theoretical connection between happiness and well-being and argued that happiness is highly favorable when valued or when it is set as the benchmark to realize one's potential and, hence, is not exclusively enough to attain high levels of well-being. Joshanloo et al. [108] examined the association between four conceptions of happiness and life satisfaction among 2715 university students and find that self-transcendence and conservatism positively affect life satisfaction, but self-directed hedonism and self-enhancement undermine life satisfaction.

Luhmann et al. [107] asserted the need for a more enhanced definition, theoretical foundation, and operationalization of happiness. Correspondingly, Carlquist et al. [109] and Judge et al. [18] opined that many social scientists and economists have highlighted on the need for conceptual clarity in well-being research, which can then provide significant insights for scientific developments and to formulate appropriate policies and programs. Additionally, from the number of papers focusing on the concepts of happiness or subjective well-being, there is a need for a well-designed and heightened definition of happiness

\subsubsection{Understanding (One)self and Body}

Extensive cross-sectional and longitudinal research report differences in psychological well-being concerning socio-economic status. The Centre for Bhutan Studies and Gross National Happiness (GNH) [110] and Judge et al. [18] observed the relationship among mental ability and psychological well-being by taking unhealthy behaviour as a mediating variable and found a significant relationship amongst them. Contextual circumstances might cause instability in otherwise moderately stable life satisfaction over long periods [36]. A distinction can be made among social organizational and individual conditions of happiness at the macro-level of society, meso level of organization, and the micro-level of individual state [111].

Chan, Wong, and Yip [112] reported a strong negative linkage among relative income depreciation and perceived happiness. However, a weak negative linkage was observed between happiness and self-rated health in the case of Hong Kong having equitable health policies. Graham et al. [81] reported that insufficient rest and leisure results in less satisfaction. A study on a sample from European countries reported that national per capita GDP increases subjective well-being, financial status, and health in advance societies, suggesting that policymakers should spend fewer funds on reducing inequalities [113].

Respondents in cities that are educated are found to be less happy than their counterparts living in rural areas and least educated. On some moral grounds, some level of virtue is required for well-being, where virtue is the intrinsic value of any human being [114-116]. Happiness is an internal condition and a reflection of good life experiences [42]. The understanding of oneself improves physiological wellbeing, which leads to better relationships that further impact performance and growth [67]. The individuals that have a strong feeling of self-deception give higher priority to their opinion about life than actual life circumstances [117]; for instance, one of the studies opined that the children involved in taking care of someone may themselves have poor health and have decreased well-being because of low self-esteem [118]. Understanding oneself lowers the divorce rate and increases marital wellbeing [62]. Conversely, it also generates a feeling of gratitude and promotes consistency, which causes happiness, and this feeling of dispositional gratitude is found to be very relevant for subjective wellbeing [119]. It is established that self-actualization is more relevant than material wealth and it is the rich who can further elaborate on this concept more realistically than the poor, who still are engaged in fulfilling their basic needs in line with the Maslow need hierarchy theory. By taking job creativity and personal autonomy as indicators of post materialistic concerns and income as a substitute of material concern, Delhey [75] discussed the relevance of understanding oneself.

Religious activities somehow decreased economic performance but may not significantly affect well-being [120]. Yogis practicing Anasakti were found to be closer to well-being than the secular population [121]. 


\subsubsection{Human-Human relationships}

Regardless of a family's economic status, social integration contributes positively to happiness [122]. Some forms of happiness, when taken to the extreme, across cultures, may cause an aversion to happiness [123]. Contextually, happiness varies across the cultures. In the western culture, individuals try to find happiness through an independent agency; whereas in Eastern Asia, culture defines happiness as a balance between self and others [110]. One of the studies reports that the observed variation in efficiency of individuals across continents established that the northern and central European countries are more efficient compared to Asian transitional economies [124]. Further, Ford et al. [125] tested the impact of cultural differences and opined that culture mediates the association from being inspired to pursuing happiness in Russia and East Asia, but the same is not valid for the US and Germany.

An aspect of happiness is likely to have relatively high marginal utility [126], leading to welfare. Happiness, if valued more, may cause psychological disappointment [106]. Caring improves the quality of life, which further increases the psychological well-being. However, caring at a very young age has a negative relationship with happiness, as the results from a study conducted among 4192 young primary school children indicated that the authorities should provide a supportive environment for confiding and seeking help [118]. Health and welfare authorities have been recommended to design policies and programs focusing on the well-being and quality of life of people with disabilities [127].

Rearing a family has been positively associated with life satisfaction [126,128]. The author reported the impact of geographical distance and time on the psychological well-being of intergenerational correlations, suggesting that if siblings stay at a distance away from their parental home then the community factors are considered to be more influential than parental characteristics [66]. An increase in the family income reportedly increased marital happiness over a short term; whereas in the long term, the relationship among the indicators was weak [62]. Family functions influence life satisfaction; Botha and Booysen [128] reported that balanced family functioning makes people more satisfied and happy in comparison to the individuals living in unstable family operations, focusing on intra-family dynamics for well-being. Eudemonic and hedonomic studies support that life satisfaction positively influences child reproduction [129]. The study reported that martial well-being across time increases, stating that higher marital bliss in a previous year will lead to a higher happiness level in the succeeding years [130]. Further, one of the studies reported a positive association between demographics and self-reported happiness and opined that married and educated people are relatively happier but having too many children reportedly damage happiness.

People through resilience develop a progressive approach towards positive emotions, leading them to life satisfaction as they develop the resources for living well [131]. A cross-country comparison of happiness suggested relational goods to be positively associated with subjective well-being [132]. The author, using the medium of narratives, established the unsettled relationship among happiness and well-being through feminine studies focusing on the western European ideology of gender equality [133]. In respect of leisure education, the author reported a significant positive relationship between happiness and leisure experiences, including challenges, awareness, boredom and distress, and happiness [42]. One of the authors used the quantile regression method to observe the positive relationship of happiness with the decreasing status of income, health, and social factors; whereas education has a positive relationship in the lower quantiles and a negative relationship at the upper quantiles with happiness [134].

One of the studies in Rwanda indicated that the valuing of friends and national pride predicted life happiness [135]. The trade of the individual determined happiness-entrepreneurs are happier than the employees and at the same time, idea contribution and the personal growth of employees lead them to experience happiness [136]. Pro-social behaviour causes happiness [85]. Shopping by media channels promotes social exclusion, which affects happiness and well-being [137]. The feeling of gratitude makes one happy. The author conducted the gratitude appreciation test (GRAT), i.e., a measure of dispositional gratitude, and the results supported the theory, concluding that gratitude is positively related to social well-being [119]. 


\subsubsection{Physical Facilities}

Physical facilities consist of physio-chemicals which help in nurturing and protecting our bodies. These physiochemical reactions produce positive sensations that make us happy or unhappy. This process depends on constant contact with the physiochemical results. Hence, it may be complicated to maintain happiness since the dependence on these facilities is temporary [138].

Extant literature supports the realization of basic material needs for a comfortable living [110]. Income inequality by unemployment leads to unhappiness [139]. Marital status through the absolute and relative increase in income in the case of women leads to marital happiness and well-being and reduces the risk of divorce. However, the increased contribution of females in the family income has a reverse effect on happiness and well-being [62]. Additionally, life events such as death, divorce, and disability have a lifelong impact on the happiness level of an individual but also returns to a set-point level referred to as the hedonic adaptation [140].

Fisher and Boulding suggest that "consumer capital" is the ultimate source of prosperity. The income-happiness relationship can be less relevant for economics as compared to the capital happiness relationship [141]. Social exclusion leads to less happiness, especially in the case of the people with mobility and disability issues, and consumers who purchase through online channels face more of unhappiness and less well-being [137]. Significant research about Asian economies reports the relevance of social integration in comparison to economic status, contrasting western economies [122].

Kroll [89] opined that material needs influence the subjective well-being of an individual, with rich people being more satisfied as compared to poor citizens. Social comparisons and hedonic adaptation can be important rationales behind the happiness-income paradox (fitted in social or income issues), such as expanding the social-capital deficit, work-life imbalance, and social inequality [142]. The research reports that more liquid wealth is more related to life satisfaction [143]. Happiness among youth is a euphemism of financial satisfaction, which further leads to life satisfaction [53]. The belief of happiness being positively correlated with income and wealth is refuted by the happiness-income paradox in international comparisons but is accepted in national comparisons [144]. Relative financial status among immigrants affects their financial well-being [145]. Oshio and Kobayashi [139,146] investigated the association between regional inequality and an individual's valuation of happiness, and concluded that areas with high-income inequality report themselves to be unhappy and unhealthy.

Literature empirically established a positive association between risk and individual well-being; the more risky the ventures, the merrier is consumer well-being [147]. The subjective concept of happiness, in contrast with the objective concept, is influenced significantly by physical facilities [148]. A direct and indirect linkage through unhealthy behaviour to occupational pressures has been established through health to subjective well-being [18]. The economic domain affects individual and social well-being and has a spillover effect on other life domains [149]. Few of the scientific studies reported substantial heritability amongst wellbeing and satisfaction with life [63,68]. Additionally, based on the fact that healthy eating leads to happiness, policymakers must focus on the nutrition issues of their citizens in order to be a happy country.

\subsubsection{Ecology}

Ecological balance leads to sustainable living. The population must be informed about the critical issues of the environment so that sustainable living can be achieved as nature is responsible for the overall well-being of the world [110]. An intercountry study using life satisfaction data empirically established a statistically significant difference in air pollution as the predictor of subjective well-being [150]. Higher carbon footprints are negatively associated with well-being. The relationship is linear, strategically guiding policymakers about the benefits of increasing well-being through decreasing carbon footprints [85].

The environment is positively associated with perceived health, which, in turn, impacts well-being [63]. Shier and Graham [151] studied the impact of the environment on the well-being of social workers and concluded a direct impact of physical, cultural, and socio-political environmental 
factors on their well-being. Additionally, Nisbet, Zelenski and Murphy [152] explored the association between nature and well-being and concluded that nature has a positive effect that is enough to overcome negative emotions and helps people recover from adverse situations, finding that nature has the potential to improve psychological health. Tella and MacCulloch [47] studied the happiness responses of 350,000 people in OECD (Organization for Economic Co-operation and Development) countries from 1975 to 1997 and concluded their negative correlation with environmental degradation (measured by sulphur oxide emissions) and crime rates. Additionally, Benjamin et al. [64] estimated high relative marginal utility for aspects relating to security while proposing a survey for an individual-level well-being index.

Safety and security are other conditions for happiness, which require governmental control and intervention. Fighting crime, and in particular violent crime, is on priority. Crime hurts victims financially and often psychologically, as in a case where a direct experience of burglary significantly reduces the victim's happiness level, indicating the higher impact of the psychological non-pecuniary costs than the pecuniary losses [153]. Average happiness and social security are positively related, but this correlation dissolves when GDP is controlled. Hence, this necessitates more research into this hidden "happiness leak" [154,155].

\subsubsection{Policy and Governance}

Extant literature reveals that subjective well-being is highly influenced by socio-political factors but the academics failed to consider the size and role of government as the determinants of well-being [156]. Life satisfaction can be seen through the lens of political ideologies since the countries having stable democracies are high on life satisfaction as compared to the countries having weak democracies [157], suggesting that governments should strengthen democracies to increase life satisfaction. Alessandrini and Jivraj [92] focused on the aspects of social impact bonds and the Gross National Happiness of Bhutan to stress on the study of individual contexts and initiatives, and further suggested the avoidance of merging different well-being agendas for fancy policymaking. The objective indicators of United Nations Developmental Program's well-being are distinct from the subjective perception of the individuals themselves [158]. Political events may influence the happiness and well-being of the population, which always increases with the increase in income of the country as material norms increase with income [76]. Countries with stable democracies have a high level of life satisfaction than countries having political and economic challenges [86,157], further stating that the political economy is an essential factor in attaining the objective of individual happiness [11].

Tenaglia [148] discussed the impact of macroeconomic variables on happiness and found a significant relationship of the outer concept of happiness with objective desires, income, and job, while a significant relationship did not exist between subjective concepts of happiness and subjective desires. Unemployment negatively impacts life satisfaction but does not affect happiness [159]. Relative income depreciation negatively impacts the perceived happiness of individuals, suggesting that policymakers develop more welfare schemes to address the feeling of deprivation [112]. The individuals' own economic situation, and overall economic conditions significantly impact one's life satisfaction, but one's economic situation has a more influential impact on well-being [160], signalling that policymakers should put more stress more on perceptions as far as life satisfaction is concerned, which may happen because of the lack of self-understanding.

According to the famous phenomena of the Easterlin paradox, happiness levels do not rise despite sustained economic growth [161]. The happiness paradox explains that the increase in the income of peers hurt the poor more than the rich [132,162]. One of the studies in China discussed the "growth paradox", arguing that life satisfaction in China has been reduced with its unprecedented economic growth and poverty reduction $[81,142]$. Happiness inequality has an inverse relationship with income growth [163]. The author argued that, in case of advanced countries, the inequality as measured by the Gini coefficient has no impact on health and well-being whereby directing policy towards the reduction 
of inequality is hardly going to affect well-being, while it is significantly evident and required in the case of developing and least developed countries [113].

In contrast, one of the studies argued that income growth does not lead to happiness once a threshold level is reached and the situation is otherwise evident in income growth deprived countries [73]. Income inequality significantly affects personal happiness [164]. Hence, the policymakers must focus on the distribution of income in such a manner that it reduces inequality and increases well-being.

A study conducted in Japan regarding the impact of income inequality on happiness indicated that people living in high inequality areas are perceived to be less happy, which further supports that people with less job stability are sensitive to inequality. The well-being of people, directing the social policymakers to mitigate inequality with an intent to promote happiness, is negatively affected by area-level inequality [139].

The study discussed the influence of crime on the psychological well-being of individuals, suggesting that policymakers stress more on the decrease of crime rates to increase psychological well-being [153]. Binder and Coad [134] observed that the relevance of income, health status, and social factors reduces with an increase in happiness levels. Healthy eating improves well-being. Hence, the government should focus on nutrition and promote natural farming to enhance healthy living [59]. A study conducted in Rwanda supported that an increase in income wellness and financial well-being increases happiness [135] and focusing on demographic and economic indicators can improve the well-being of the economy. The literature further supports entrepreneurship to promote well-being [136]. In a cross-country study, the author discussed that an increase in economic freedom is positively associated with an improvement in well-being up to a level, but over time the increasing economic freedom decreases subjective well-being, keeping other factors constant [165].

\subsubsection{Measurement of Happiness}

In a first attempt to revisit the concept of happiness, Richard Easterlin reported that, regardless of the growth in GDP per capita, the happiness level of the citizens do not improve over the long term $[9,10]$. As a response to this research, Adler and Seligman [166] suggested that subjective well-being is correlated with different aspects of life (including income), and hence, multi-dimensional indexes that are descriptive should be constructed, and various factors reflecting the citizens' own preferences and values can be incorporated. Additionally, measurement errors reported that happiness is not affected by the nation's inequality, but by changing the measurements, the corrected results stated that income inequality does affect happiness inequality [77].

Lewis and Joseph [94] also investigated the internal reliability and validity of a depression-happiness scale, indicating greater happiness and satisfaction with life. Complementarily, Joseph et al. [96] developed a short six-item form of the depression-happiness scale and also examined its validity and reliability, and additionally confirmed it to have a desirable discriminant validity score with measures of happiness, depression, and personality.

Benjamin et al. [64] proposed foundations and a methodology for a survey to track well-being at an individual level, emphasizing the utility on "fundamental aspects" of well-being and concluded high relative marginal utilities for aspects relating to family, health, security, freedom, values, and a few more.

Lucas and Donnellan [167] investigated long-lasting stability and change of well-being using a statistical model, STARTS, to analyze life satisfaction data and found a considerable degree of instability that might be due to contextual circumstances. Furthermore, Roberts et al. [100] recommended a model that explains the negative association between materialism and life satisfaction and concluded negative effects, positive effects and gratitude as essential factors associating materialism and dissatisfaction with life.

Conversely, Bond and Lang [168] highlighted that happiness is ordinal and so, using survey responses that involved interval and ratio scales, the ordinal happiness data is impossible to state 
and appropriate conclusions cannot be drawn. Additionally, Adler and Seligman [166] suggested that, rather than targeting GDP growth figures, the governments should provide better well-being conditions through better public services, urban planning, and a stronger social safety net.

\subsection{Mechanism}

Table 3 discusses the independent, mediating, and control variables identified from the various empirical studies from the set of papers extracted from the Web of Science. Diverse surveys and scales have been developed in this field, and hence it is imperative to highlight the variables in each category, which will also assist a future researcher in the selection of the appropriate variables desired for conducting empirical research. For all the below mentioned paper, the dependent variable has been termed happiness, subjective well-being, life satisfaction, well-being or welfare, and as discussed in Section 2, we have used them interchangeably for a better understanding of the concept on the whole [29-32,42]. 
Table 3. Variables causing happiness/ subjective well-being/ life satisfaction.

\begin{tabular}{|c|c|c|c|}
\hline Independent Variable & Mediating/ Moderating Variable & Control Variable & Reference \\
\hline Altruism & - & Family size and family income & Phelps [169] \\
\hline $\begin{array}{l}\text { Income, health status, employment, and, } \\
\text { financial satisfaction }\end{array}$ & - & - & Boo et al. [29] \\
\hline $\begin{array}{l}\text { Financial behavior namely managing } \\
\text { expenses (directly), controlling balance and } \\
\text { saving }\end{array}$ & $\begin{array}{l}\text { Financial satisfaction, academic } \\
\text { performance, academic satisfaction }\end{array}$ & - & Xiao et al. [53] \\
\hline $\begin{array}{l}\text { Adaptation life events (marital transition, } \\
\text { unemployment, and disability)—Hedonic } \\
\text { Adaptation }\end{array}$ & - & - & Lucas [140] \\
\hline $\begin{array}{l}\text { Mutual (familial) altruism between mother } \\
\text { and child, and father and child }\end{array}$ & - & - & Ong et al. [170] \\
\hline $\begin{array}{l}\text { Anasakti-Non-attachment and selfless duty } \\
\text { orientation }\end{array}$ & - & - & Banth and Talwar [121] \\
\hline General mental ability & $\begin{array}{l}\text { Unhealthy behaviors, education, and } \\
\text { occupational prestige }\end{array}$ & $\begin{array}{l}\text { Sex, age, and childhood socioeconomic } \\
\text { status }\end{array}$ & Judge et al. [18] \\
\hline Family background and community & - & Age & Schnitzlein and Wunder [66. \\
\hline Area-level income inequality. & $\begin{array}{l}\text { Gender, age, marital and educational status, } \\
\text { occupational level, household income, social } \\
\text { capital, and political views }\end{array}$ & $\begin{array}{l}\text { Household income, } \\
\text { prefecture mean income. }\end{array}$ & Oshio and Kobayashi [139] \\
\hline Adaptation & - & - & Tsutsui and Ohtake [171] \\
\hline Higher subjective career success & - & Years spent at work & Proyer, Annen, et al. [172] \\
\hline Religion & - & $\begin{array}{l}\text { Personality traits, age, gender, education, } \\
\text { income, marital status, country of birth, } \\
\text { health }\end{array}$ & Headey et al. [173] \\
\hline Employment Status & - & $\begin{array}{l}\text { Household income, number of children, } \\
\text { partnership, health, own and overall } \\
\text { economic situation }\end{array}$ & Maennig and Wilhelm [160] \\
\hline Income Inequality & Hope & - & Cheung [174] \\
\hline
\end{tabular}


Table 3. Cont.

\begin{tabular}{|c|c|c|c|}
\hline Independent Variable & Mediating/ Moderating Variable & Control Variable & Reference \\
\hline Valuing happiness & $\begin{array}{l}\text { Participant's disappointment at their } \\
\text { feelings. }\end{array}$ & Experimentally induced to value happiness & Mauss et al. [106] \\
\hline $\begin{array}{l}\text { Married women's income and its proportion } \\
\text { of total family income }\end{array}$ & - & $\begin{array}{l}\text { Respondent's race, gender, age, education, } \\
\text { years of marriage, and number of children }\end{array}$ & Stacy J. Rogers and DeBoer [62] \\
\hline $\begin{array}{l}\text { School involvement, appreciation of subjects, } \\
\text { others' happiness, and prosocial behavior }\end{array}$ & - & - & Backman [28] \\
\hline $\begin{array}{l}\text { Labor union membership across high- and } \\
\text { low- income countries }\end{array}$ & - & $\begin{array}{l}\text { Average annual unemployment rate, fixed } \\
\text { country characteristics, time period } \\
\text { characteristics }\end{array}$ & Charman and Owen [175] \\
\hline $\begin{array}{l}\text { Self-transcendence, self-directed hedonism, } \\
\text { conservation, and self-enhancement }\end{array}$ & - & Age, gender and national individualism & Joshanloo et al. [108] \\
\hline $\begin{array}{l}\text { Self-evaluations, positive and negative } \\
\text { affectivity and Neutral Objects Satisfaction } \\
\text { Questionnaire }\end{array}$ & - & - & Piccolo et al. [176] \\
\hline $\begin{array}{l}\text { Four domains of leisure (challenge, boredom, } \\
\text { awareness, and distress) }\end{array}$ & - & - & Lepp, [42] \\
\hline Burglary and robbery (Crime) & - & - & Kuroki [153] \\
\hline Socially engagement & Cross-cultural differences & Age and gender & Ford et al. [125] \\
\hline Debt & Partially moderated by income & $\begin{array}{l}\text { Gender, marital status, and employment } \\
\text { status }\end{array}$ & Tay et al. [149] \\
\hline Living in a democratic country & - & - & Loubser and Steenekamp [157] \\
\hline $\begin{array}{l}\text { Absolute income, positional and relational } \\
\text { goods, and social capital }\end{array}$ & - & $\begin{array}{l}\text { Age, gender, education, employment and } \\
\text { marital status }\end{array}$ & Sarracino [132] \\
\hline Employment and unemployment & - & - & Strizovic and Mratinkovic [80] \\
\hline Ethical leadership & Job satisfaction & Gender and Income & Conna Yang [177] \\
\hline Immigration & - & $\begin{array}{l}\text { Immigrants continents of origin, original } \\
\text { country's religion, age, income, and } \\
\text { education }\end{array}$ & Gatina [145] \\
\hline Income inequality & - & $\begin{array}{l}\text { Per capita GDP, income, age, gender, } \\
\text { education, religion, and marital status }\end{array}$ & Zagorski et al [113] \\
\hline
\end{tabular}


Table 3. Cont

\begin{tabular}{|c|c|c|c|}
\hline Independent Variable & Mediating/ Moderating Variable & Control Variable & Reference \\
\hline Religion & - & - & Campante and Yanagizawa [120] \\
\hline $\begin{array}{l}\text { Social exclusion and shopping time through } \\
\text { every channel per week }\end{array}$ & - & Gender, age, and area of residence & Dennis et al. [137] \\
\hline Belief in a just world & - & - & Correia et al. [178] \\
\hline Motherhood & - & $\begin{array}{l}\text { Age, year of survey, number of years in the } \\
\text { panel, education, relationship status, } \\
\text { household members, working hours and } \\
\text { household income }\end{array}$ & Baetschmann et al. [126] \\
\hline Income inequality & - & $\begin{array}{l}\text { Income below } \$ 500 \text { per year, gender, age, } \\
\text { age-squared, marital status, labor-force } \\
\text { status, and education }\end{array}$ & Clark et al. [163] \\
\hline $\begin{array}{l}\text { Income, family unity, and togetherness, } \\
\text { friendships, job/working environment, } \\
\text { number of children and education }\end{array}$ & - & - & Mahadea and Rawat [73] \\
\hline Social networking sites & - & - & Dogan [179] \\
\hline Spiritual well-being & - & - & Rowold [180] \\
\hline Unemployment and income & - & $\begin{array}{l}\text { Age, gender, occupation, education, } \\
\text { relationship status, religion, }\end{array}$ & Böckerman and Ilmakunnas [159] \\
\hline $\begin{array}{l}\text { Psychological need satisfaction, work } \\
\text { performance, relationships, health and } \\
\text { longevity and income }\end{array}$ & $\begin{array}{l}\text { Age, education level ethnicity, gender, } \\
\text { socioeconomic status, and personality traits }\end{array}$ & & Kushlev et al. [181] \\
\hline Per capita income and air pollution levels & - & $\begin{array}{l}\text { Socio-demographic characteristics and } \\
\text { personality traits }\end{array}$ & Welsch [150] \\
\hline $\begin{array}{l}\text { Age, household income, education, } \\
\text { employment status, relationship status, long } \\
\text { term health condition, alcohol, non-smoker, } \\
\text { eating patterns, BMI, exercise, }\end{array}$ & - & - & Mujcic and Oswald [59] \\
\hline $\begin{array}{l}\text { Social relationships, personality, volitional } \\
\text { activities, behavioral activities, and cognitive } \\
\text { activities }\end{array}$ & - & - & Caunt et al. [39] \\
\hline
\end{tabular}


Table 3. Cont

\begin{tabular}{|c|c|c|c|}
\hline Independent Variable & Mediating/ Moderating Variable & Control Variable & Reference \\
\hline Family functioning & - & $\begin{array}{l}\text { Age, gender, age squared, educational } \\
\text { attainment, race, household size household } \\
\text { expenditure, religion, employment, health } \\
\text { and marital status }\end{array}$ & Botha and Booysen [128] \\
\hline Income, social relations, and health & - & $\begin{array}{l}\text { Age, gender, education, job status, marital } \\
\text { status, and number of children }\end{array}$ & Binder and Coad [134] \\
\hline $\begin{array}{l}\text { Financial satisfaction, personal autonomy } \\
\text { (free of choice), job creativity }\end{array}$ & - & $\begin{array}{l}\text { Gender, age, age squared, income, } \\
\text { relationship status, employment, education } \\
\text { and self-rated health }\end{array}$ & Delhey [75] \\
\hline Gelotophobia (fear of being laughed at) & - & - & Proyer, Ruch, et al. [182] \\
\hline $\begin{array}{l}\text { Gender, relationships (family, friends and } \\
\text { marital status), self-concept (academic } \\
\text { performance, self-esteem, and purpose in } \\
\text { life) and religion }\end{array}$ & - & Age & Chui and Wong [183] \\
\hline Income, health, and education & - & $\begin{array}{l}\text { Age, number of children, gender, } \\
\text { unemployment, marital status, religiosity } \\
\text { and trust }\end{array}$ & Kroll [89] \\
\hline Goal motivesand physical health & - & - & Miquelon and Vallerand [46] \\
\hline Gratitude & - & - & P C Watkins et al. [184] \\
\hline $\begin{array}{l}\text { Income level, state welfare and life } \\
\text { expectancy }\end{array}$ & - & $\begin{array}{l}\text { The average hours of work, environmental } \\
\text { degradation, crime, divorce rate, marital } \\
\text { status, openness to trade, inflation and } \\
\text { unemployment (all } \\
\text { controlled for country and year) }\end{array}$ & Di Tella and MacCulloch [47] \\
\hline $\begin{array}{l}\text { Health impairment, socioeconomic status } \\
\text { (SES), and social support }\end{array}$ & - & - & Bishop et al. [45] \\
\hline $\begin{array}{l}\text { Socioeconomic status (SES), and social } \\
\text { support }\end{array}$ & Health impairment & & \\
\hline
\end{tabular}


Table 3. Cont

\begin{tabular}{|c|c|c|c|}
\hline Independent Variable & Mediating/ Moderating Variable & Control Variable & Reference \\
\hline $\begin{array}{l}\text { Household expenditure and greenhouse } \\
\text { gas-based carbon footprints }\end{array}$ & - & $\begin{array}{l}\text { Age, gender, marital status, immigrant, } \\
\text { employment status, number of children, } \\
\text { health measures, education, income and } \\
\text { expenditure measures, hours of work, the } \\
\text { leisure of free time measure, personality } \\
\text { traits, social desirability and location } \\
\text { measures }\end{array}$ & Ambrey and Daniels [85] \\
\hline $\begin{array}{l}\text { Physical health status, home, and car } \\
\text { ownership, education, income, marital status } \\
\text { and leisure time }\end{array}$ & - & Employment status and regionality & Graham et al. [81] \\
\hline Health & Genetic and environmental factors & Perceived health & Roysamb et al. [63] \\
\hline $\begin{array}{l}\text { Psychological well-being, demographics, } \\
\text { self-efficacy, hopefulness, life satisfaction, } \\
\text { and stress }\end{array}$ & - & - & Heizomi et al. [67] \\
\hline $\begin{array}{l}\text { Confidence in civil services, social security, } \\
\text { health care, pride in one's country, religious } \\
\text { activities, self-control, country } \\
\text { characteristics, stable relationship, income, } \\
\text { and social capital }\end{array}$ & - & $\begin{array}{l}\text { Age, gender, education and number of } \\
\text { children }\end{array}$ & Gundelach and Kreiner [87] \\
\hline $\begin{array}{l}\text { Household's financial satisfaction and } \\
\text { income, health status, freedom and life } \\
\text { control, religious activities, the importance } \\
\text { of friends, national pride }\end{array}$ & - & $\begin{array}{l}\text { Socio-economic and demographic variables } \\
\text { i.e. age, gender, employment status, marital } \\
\text { status and education }\end{array}$ & Ngamaba [135] \\
\hline $\begin{array}{l}\text { Household income, rural versus urban } \\
\text { location, expectation, and comparison to } \\
\text { one's situation in past and other's situation }\end{array}$ & - & $\begin{array}{l}\text { Age, gender, marital status, employment } \\
\text { status, and education }\end{array}$ & Caner [185] \\
\hline $\begin{array}{l}\text { Self-reported health, limiting health } \\
\text { conditions; and physical health. }\end{array}$ & - & $\begin{array}{l}\text { Physical and mental health, smoking, social } \\
\text { support, physical activity, body mass index } \\
\text { and demographics }\end{array}$ & Siahpush et al. [49] \\
\hline $\begin{array}{l}\text { Life experiences during an individual's } \\
\text { anchor periods and the emotions, thereby }\end{array}$ & - & Socio-demographic factors & Shmotkin and Shrira [186] \\
\hline $\begin{array}{l}\text { Personality traits, income status, social } \\
\text { rootedness and social support }\end{array}$ & - & - & Cox [97] \\
\hline
\end{tabular}


Table 3. Cont

\begin{tabular}{|c|c|c|c|}
\hline Independent Variable & Mediating/ Moderating Variable & Control Variable & Reference \\
\hline Caring & - & Age & [118] \\
\hline Life circumstances & Personality traits & - & Lucas and Donnellan [167] \\
\hline Liquid wealth & $\begin{array}{l}\text { Financial well-being (investments, total } \\
\text { spending, and indebtedness) }\end{array}$ & Age, employment, and relationship & Ruberton et al. [143] \\
\hline \multirow{2}{*}{ Income inequality } & Perceived fairness and general trust & - & \multirow{2}{*}{ Oishi et al. [78] } \\
\hline & - & $\begin{array}{l}\text { Perceived fairness, general trust, and } \\
\text { household income }\end{array}$ & \\
\hline Income inequality & - & $\begin{array}{l}\text { Age, education, gender, children (if any), } \\
\text { household size, ethnicity, marital status, } \\
\text { health status, year of data collection, per } \\
\text { capita gross domestic product (GDP) growth } \\
\text { rate and employment status }\end{array}$ & Yu and Wang [164] \\
\hline \multirow{3}{*}{ Economic growth (GDP) } & Income inequality & - & \multirow{3}{*}{ Oishi and Kesebir [187] } \\
\hline & - & $\begin{array}{l}\text { Gender, age, marital status, } \\
\text { chief-income-earner status and education } \\
\text { level }\end{array}$ & \\
\hline & - & Income inequality & \\
\hline \multirow[t]{2}{*}{ Regional Inequality } & \multirow[t]{2}{*}{-} & $\begin{array}{l}\text { Gender, age, education status, employment } \\
\text { status, income level, political orientation, } \\
\text { mean income, the proportion of people aged } \\
60 \text { and above }\end{array}$ & \multirow[t]{2}{*}{$\begin{array}{l}\text { Oshio and Kobayashi } \\
\text { [146] }\end{array}$} \\
\hline & & $\begin{array}{l}\text { Including all above and per capita budget } \\
\text { expenditure by the government }\end{array}$ & \\
\hline Social comparison and adaptation of income & - & $\begin{array}{l}\text { Age, gender, education, marital status, } \\
\text { health status, location, employment status, } \\
\text { work hours, volunteer work, commuting } \\
\text { time }\end{array}$ & Paul and Guilbert [162] \\
\hline Risk exposure & - & - & Ayadi et al. [147] \\
\hline $\begin{array}{l}\text { Gender, education, marital status, ethnicity, } \\
\text { employment relations, children, income, } \\
\text { work status (personal development and } \\
\text { ideas generation) }\end{array}$ & - & - & Mahadea and Ramroop [136] \\
\hline
\end{tabular}


Table 3. Cont.

\begin{tabular}{|c|c|c|c|}
\hline Independent Variable & Mediating/ Moderating Variable & Control Variable & Reference \\
\hline Economic freedom & - & $\begin{array}{l}\text { Religious freedom, crime, violence, life and } \\
\text { health satisfaction, corruption, state } \\
\text { dependence, income, unemployment, social } \\
\text { capital and inequality }\end{array}$ & Spruk and Keseljevic [165] \\
\hline Family members well-being & - & Genetic relatedness and homophily & Matteson et al. [188] \\
\hline Income inequality & - & - & Delhey and Kohler [77] \\
\hline Personal value of happiness & - & - & Luhmann et al. [107] \\
\hline $\begin{array}{l}\text { Conception of happiness (health, } \\
\text { relationships, knowledge, work, material } \\
\text { goods, and freedom. ) }\end{array}$ & Gender and period of life & - & Bojanowska and Zalewska [189] \\
\hline $\begin{array}{l}\text { Self-rated health, perceived (ethnic) } \\
\text { discrimination, education, housing, income, } \\
\text { and ethnic group identification }\end{array}$ & - & Gender, age, and country & Kamberi et al. [190] \\
\hline $\begin{array}{l}\text { Age, health, gender, level of education, } \\
\text { religion, nationality, marital status, } \\
\text { employment status, number of children, } \\
\text { income, family, friends, leisure time, politics, } \\
\text { work in life, trust factors between people, } \\
\text { and political orientation }\end{array}$ & - & - & Selim [48] \\
\hline $\begin{array}{l}\text { Affective and interpersonal-social } \\
\text { self-efficacy beliefs (with parents and peers) }\end{array}$ & - & - & Caprara et al. [191] \\
\hline Materialism & $\begin{array}{l}\text { Gratitude and positive affect - moderators } \\
\text { and negative affect -mediator }\end{array}$ & - & Roberts et al. [100] \\
\hline $\begin{array}{l}\text { Selective optimization and compensation } \\
\text { (SOC) }\end{array}$ & Age & $\begin{array}{l}\text { Gender, education years, working status, } \\
\text { self-reported health. }\end{array}$ & Teshale and Lachman [192] \\
\hline Marital trajectories & - & $\begin{array}{l}\text { Age, gender, education, number of children, } \\
\text { marital status, homogamy, hours of work, } \\
\text { income, religiosity }\end{array}$ & Dush et al. [130] \\
\hline Marital well-being & Time & & Ruvolo [61] \\
\hline Family structure (marriage and parenthood) & Cultural differences & $\begin{array}{l}\text { Age, education, employment status, } \\
\text { household income and GDP per capita }\end{array}$ & Vanassche et al. [193] \\
\hline
\end{tabular}


Table 3. Cont

\begin{tabular}{|c|c|c|c|}
\hline Independent Variable & Mediating/ Moderating Variable & Control Variable & Reference \\
\hline $\begin{array}{l}\text { Economic well-being (GDP, employment, } \\
\text { wages, taxes, and inflation) }\end{array}$ & - & - & Druzic and Majstorovic [194] \\
\hline Psychological well-being & - & Gender, age, and ethnicity & Linley et al. [50] \\
\hline Externality of happiness beliefs & $\begin{array}{l}\text { Lower levels of personal growth initiative } \\
\text { and psychological resilience }\end{array}$ & Age and gender & Joshanloo [102] \\
\hline $\begin{array}{l}\text { Migration (adaptation, social comparison } \\
\text { and economic integration (relative income } \\
\text { position)) }\end{array}$ & - & $\begin{array}{l}\text { Age, age squared, marital status, } \\
\text { employment, subjective health and } \\
\text { household composition }\end{array}$ & Melzer and Muffels [195] \\
\hline Migration and health & - & $\begin{array}{l}\text { Age, gender, education, age squared, } \\
\text { religious services, income, labor force status, } \\
\text { life expectancy at birth and infant mortality } \\
\text { (per } 1000 \text { births) }\end{array}$ & Ljunge [196] \\
\hline Migration & $\begin{array}{l}\text { Economic well-being and family } \\
\text { disintegration }\end{array}$ & - & Jones [65] \\
\hline Relative income & - & $\begin{array}{l}\text { Age, education, housing ownership, marital } \\
\text { status, children, gender, disabilities, region } \\
\text { and labor-force status }\end{array}$ & Boyce et al. [74] \\
\hline Social capital & - & $\begin{array}{l}\text { Age, children, gender, marital status, } \\
\text { religious services and work status }\end{array}$ & Sarracino [197] \\
\hline Age & Race and gender & Employment and marital status & Twenge et al. [198] \\
\hline Self-enhancing tendencies & - & - & Wojcik and Ditto [199] \\
\hline $\begin{array}{l}\text { Multidimensional poverty (income, } \\
\text { schooling, health, and social protection) }\end{array}$ & - & Gender, age, and marital status & Nozaki and Oshio [200] \\
\hline $\begin{array}{l}\text { Objective measurement of household } \\
\text { poverty }\end{array}$ & - & $\begin{array}{l}\text { Gender, age and marital status, caste, } \\
\text { household income educational status and } \\
\text { health status }\end{array}$ & Strotmann and Volkert [91] \\
\hline Use of time & - & $\begin{array}{l}\text { Gender, age, education and employment } \\
\text { status }\end{array}$ & Zuzanek and Zuzanek [201] \\
\hline
\end{tabular}


Table 3. Cont

\begin{tabular}{|c|c|c|c|}
\hline Independent Variable & Mediating/ Moderating Variable & Control Variable & Reference \\
\hline Paternal and maternal unemployment status & Age of the child & $\begin{array}{l}\text { Age and gender of the child, age, education, } \\
\text { health and marital status of the father and } \\
\text { mother, regional and year dummies, and } \\
\text { household income }\end{array}$ & Powdthavee and Vernoit [202] \\
\hline \multirow{2}{*}{$\begin{array}{l}\text { Regulatory focus (promotion and prevention } \\
\text { foci) }\end{array}$} & - & Self-control & \multirow{2}{*}{ Ouyang et al. [203] } \\
\hline & Self-control & - & \\
\hline $\begin{array}{l}\text { Democratic competition, ideological } \\
\text { complexion of governments and qualitative } \\
\text { features of the welfare state }\end{array}$ & - & $\begin{array}{l}\text { Unemployment, real per-capita GDP and } \\
\text { individualism }\end{array}$ & Radcliff [86] \\
\hline Time & - & - & DeJonge et al. [204] \\
\hline Risk preferences & Poverty & - & Tesfu [205] \\
\hline Inflation and unemployment & - & $\begin{array}{l}\text { Personal characteristics, year effects, country } \\
\text { fixed effects, and country-specific time trends }\end{array}$ & Di Tella et al. [206] \\
\hline Progressive taxation & Income inequality & $\begin{array}{l}\text { Stock market performance, inflation rate, } \\
\text { unemployment rate, ruling political party, } \\
\text { and crime rates }\end{array}$ & Oishi et al. [93] \\
\hline Public sector employment & $\begin{array}{l}\text { Relative deprivation in economic and social } \\
\text { status }\end{array}$ & $\begin{array}{l}\text { Age, marital status, education, health status, } \\
\text { household registration status, gender, } \\
\text { ethnicity, job status, comprehensive income, } \\
\text { and Communist Party membership }\end{array}$ & Hu [207] \\
\hline $\begin{array}{l}\text { Free-floating anxiety, obsessionality, phobic } \\
\text { avoidance, hysteria, and depression }\end{array}$ & - & - & Joseph et al. [96] \\
\hline
\end{tabular}


Happiness is essential not just for the well-being of individuals but for the well-being of society, and to ensure the maximization of happiness, it is necessary to consider more than just money $[1,2,4]$. Global efforts have been growing to consider these factors; for example, Bhutan developed the Gross National Happiness Index, or the Social Impact Bonds in United Kingdom [92] which, along with economics, considers other social problems in determining the well-being of their citizens. There is need to focus on people's experiences to obtain a deeper understanding of how economic growth affects the well-being of people. However, a lot of economists have concluded that relative income matters the most to the people, which ultimately affects their happiness level $[112,136,165,185]$. People often make choices that involve a mixed relationship between their existing preferences (happiness) and the options that provide the most significant immediate appeal at the cost of long-term happiness (such as, taking drugs and overeating). A recurring debate discusses people's preferences and a well-known study by Henrich et al. [208] concluded that preferences over economic choices are not derived externally but are rather determined by the interactions between the economic and social interactions of everyday life.

Majority of the studies have controlled for socio-demographic variables including age, gender, education, unemployment, and other variables. There are 31 mediating variables, while in some cases, the socio-demographic variables, namely age and gender, are also used as mediating variables $[13,181,209]$.On the other hand, with respect to the independent variable, income and other income-related variables, namely, absolute or per capita income [132], relative income [74,195], household income [59,135], level of income or area-level income inequality $[78,139,164,174]$ are seen as the highest independent variables in impacting happiness/ subjective well-being/ life satisfaction.

\section{Gaps in the Extant Literature}

The agenda of this research was to consolidate the literature already published over the years on the concept of happiness concerning the various aspects highlighted by the researchers in earlier studies. The economics of happiness raises a list of research gaps that still need to be addressed. These include the implications of well-being findings for national indicators and economic growth patterns. Numerous researchers, including Carlquist et al. [117] and Ford et al. [132], have advocated the creation of a national well-being account to complement the national income accounts. Lloyd [118] noted that in post-modern societies, it is vital to study the association between money, sustainable development, economic growth, and human happiness. This appeals for a broader index that can be used to measure the ultimate social goal, i.e., happiness and prosperity.

Additionally, the OECD Guidelines on Measuring Subjective Well-Being [210] suggest that survey designers incorporate pitfalls such as cultural biases (that are difficult to capture) by employing counterfactuals, vignettes, and migrant data. Graham [5] highlighted the potential biases in survey data, including the difficulties associated with analyzing such data, and this further advocates the need for well-being data of superior quality, and in particular panel data that can further incorporate the existing limitations, and facilitate in assessing the most appropriate directions of causality (e.g. causality between income and happiness, health and happiness, education and happiness). Better data complemented with sophisticated econometric techniques are the requirements that allow more reliable analysis and results.

Extant literature highlights that economic growth is necessary but is not exclusively enough for poverty reduction, highlighting the need for policies based on individual welfare assessments rather than general political or public policies [5]. Our results suggested prioritizing the conceptualization of happiness while computing the happiness level at an individual or a collective level. Baetschmann et al. [126] highlighted that research on subjective well-being misses out on the question of what happiness is, and instead focused more on the factors that determine the individuals' happiness and their consequences.

After tracing the significant developments of happiness research in economics, the study highlighted suicide rates, security, religion, social inequality, and freedom as the additional issues to be 
considered for future research on happiness. Furthermore, the study recommended that governments establish conditions enabling individuals to report happiness independently from political pressure to answer strategically for impressive happiness level figures at the macro level. The effects of social policy factors, including welfare budget and income inequality on national competitiveness and happiness, are imperative and should be considered while constructing well-being indexes. The impact of the physical environment, including weather, air quality, carbon emissions as well as security and safety from theft and crime on well-being, needs more attention.

\section{Directions for future research}

Figure 4 depicts that the human beings want to live in a state of happiness and prosperity [1], and the most crucial factor for a human being's happiness is definite human conduct [2]. However, the majority of the people do not know how to understand their own needs, aspirations, and desires, which theoretically is referred to as understanding oneself [3]. Understanding oneself is a way to mental happiness, which further helps in the attainment of spiritual and material happiness $[180,211]$. It also assists in setting the right framework of values involving actions directed towards the realisation of goals and aspirations.

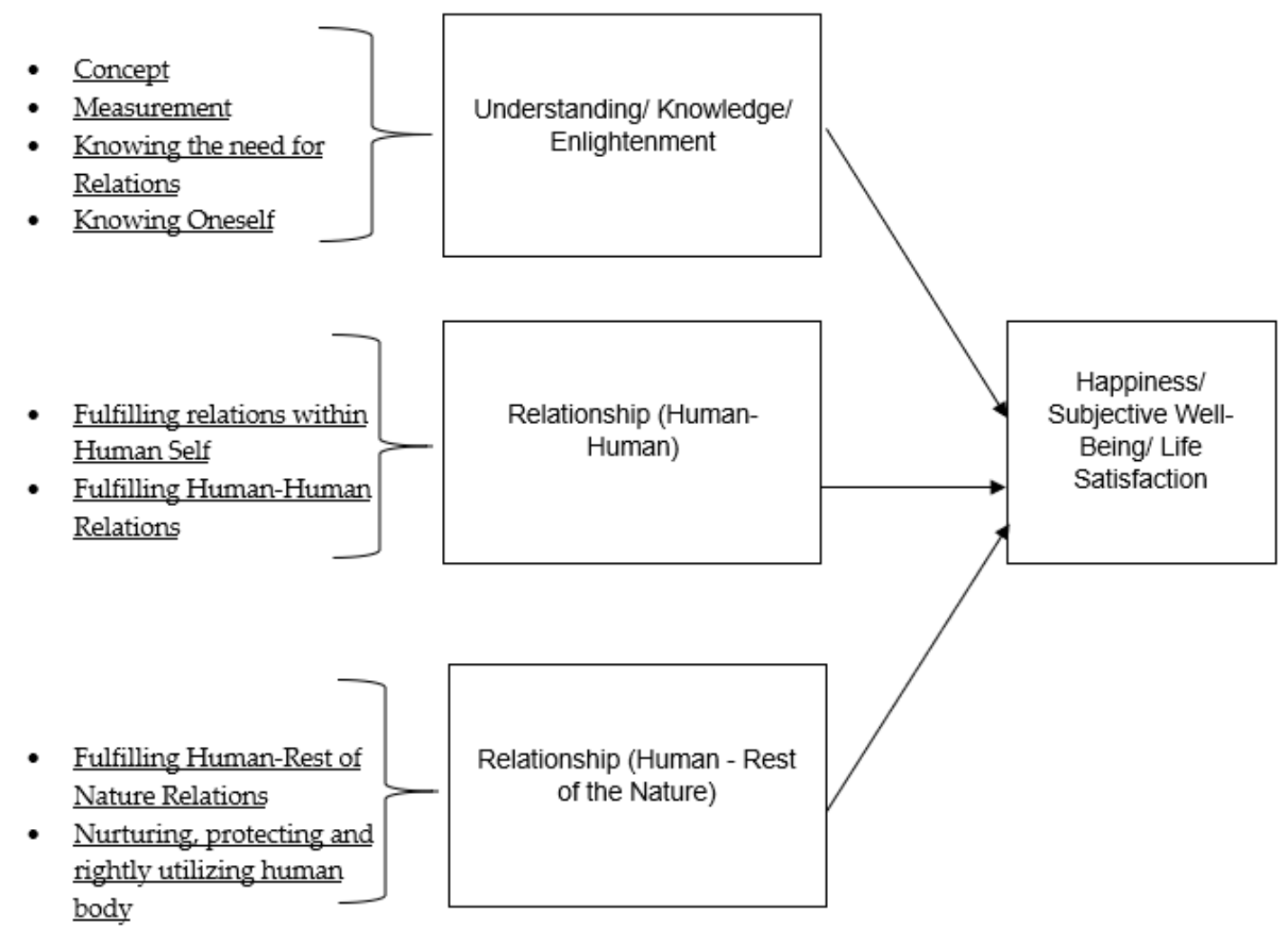

Figure 4. Human happiness integrative framework.

Utility is the branch of economics that is most equivalent to the concept of happiness. Jeremy Bentham, the founder of utilitarian theory, emphasized the direction of an individual's conduct and government policies towards stimulating greater happiness [212]. The study of economics and happiness will assist in setting up a new theoretical consideration about the right taxation derived from the findings of the utility function. Growth theory, on the other hand, has limited discussion about social factors, the relevance of which has already been empirically established [213], raising a concern for policymakers to consider social factors and utility while framing public policy. Frey [214] further emphasized on the measurement of experienced utility by using psychologists' tools of measuring subjective well-being, and the form in which human beings value goods and services and 
the non-material value for social relations and autonomy. On the other hand, Joshanloo \& Dan [123] highlighted that individuals across nations might not value happiness equally. Hence, Zwolinski [215] suggested that academicians and researchers should not assume happiness to be a "supreme universal good" unless there is a specific concept of happiness that every culture or individual can relate to.

Happiness is momentarily linked to physical facilities, with a feeling of acquiring as much as one can. It is this feeling to possess limitlessly, due to the lack of understanding of one's own needs, which ultimately creates all the trouble within the system, leading to feelings of envy and insecurities. The same is also evident from the literature, where income inequality leads to lower levels of happiness, majorly due to social comparisons. This inherent presumption behind physical facilities is that accumulating material wealth provides mental happiness but makes one spiritually unhappy [211]. The act of hoarding not only effects the relationships between individuals but also destructs ecology and the environment, ultimately threatening the survival of the entire human race.

Understanding oneself is not the only factor, it is also important to know about the need for relationships. Just as discussed above, it is equally imperative for the individual to understand the need for relationships. Social capital and relation goods are relevant to the well-being of both developed and developing countries [132]. However, nowadays, people interact with each other based on false assumptions and without knowing the expectation of the other person, which further hampers the relation as people assume that the only important thing is wealth accumulation, and everything else will fall into place. This incorrect assumption distorts human to human relations on the grounds of wealth and greed. The only way to resolve it is to have an understanding of these relationships. A similar case is applicable in relationship with nature, where it is firstly imperative to understand our own needs and desires, our requirement for physical facilities, a clear difference between wealth and prosperity, and further the need to understand the harmony with nature and how to maintain its consistency.

Hence, to continuously be able to fulfil the basic human aspirations of happiness and prosperity, it is essential to gain the right understanding of oneself, of others, namely, the family, society and rest of nature, and how it ensures continuous happiness. This understanding comes with the transformation of self-realization that human is the coexistence of self and body, while the body is the material entity. This understanding further broadens the needs of self being temporary and transient-namely hunger and thirst—while the need of the body is not materialistic but permanent—namely, love and respect. Once our desires and aspirations are based on natural acceptance then we can live in harmony within our self. Hence, the overall goal must include the right understanding at the individual, family, society, and nature (environment) levels.

\section{Conclusions}

There is a contradiction between the new insights and the conventional theories of happiness and economics [216]. Hence, Frey [214] coined the new division of economics as revolutionary, since it transformed the methods of research with a new measure of utility. Happiness and economics emphasize upon conceptual clarities, as individual utility functions can be derived from the surveys [216]. This paper views economic concepts through the lens of individual, society, and environment levels that recognizes the progress so far, highlighting the research gaps and further remarks on the avenues with scope for future research. Human happiness has increasingly been gathering the attention of researchers and policymakers in the field of economics and business, and has grown substantially in terms of concepts, methods, and approaches. The integrative framework proposed by this paper specifies the independent factors directly impacting human happiness based on three factors including the understanding or knowledge, human-human relationships and the human-nature relationship. To steer future scholarships, we categorized the literature into eight themes (conceptualization, understanding of oneself and body, human-human relations, physical facilities, ecology, policy and governance, and the measurement of happiness), providing a more systemic and holistic view to the concept of human happiness. Future researchers would do well to study the economics of happiness 
by empirically surveying the levels of human knowledge, human-human relationships, and the human-rest-of-nature relationship.

Author Contributions: Conceptualization: G.D.S., M.M.; Methodology: G.D.S., M.J.; Formal analysis and investigation: M.J., M.M.; Writing: M.J., M.M.; Supervision: G.D.S., M.M.

Funding: No specific funding was received for this study. However, upon acceptance of the paper, an application for funding the article processing charges shall be submitted to Guru Gobind Singh Indraprastha University, New Delhi. The authors thank the university in anticipation of this funding.

Acknowledgments: We are grateful to our employers - Guru Gobind Singh Indraprastha University and State Bank Institute of Credit and Risk Management - for providing us with the time during the course of our research, and the infrastructure to smoothly carry out our research.

Conflicts of Interest: The authors declare that they have no conflict of interest.

\section{References}

1. Nagraj, A. Jeevan Vidya-An Introduction; Gupta, R., Ed.; Jeevan Vidya Prakashan: Amarkantak, India, 2008.

2. His Holiness the Dalai Lama A human approach to world peace. J. Hum. Values 2012, 18, 91-100. [CrossRef]

3. Gaur, R.R.; Sangal, R.; Bagaria, G.P. Human Values and Professional Ethics, 1st ed.; Excel Books: New Delhi, India, 2009; ISBN 8174467815.

4. Irwin, T. Nicomachean Ethics; Hackett Publishing Company: Indianapolis, IN, USA, 1985; ISBN 0915145669.

5. Graham, C. The Economics of happiness: Insights on globalization from a novel approach. World Econ. 2005, 6, 41-55.

6. Diener, E. Subjective well-being. Psychol. Bull. 1984, 95, 542-575. [CrossRef] [PubMed]

7. Hallberg, M.; Kullenberg, C. Happiness Studies. Nord. J. Sci. Technol. Stud. 2019, 7, 42-50. [CrossRef]

8. Hsee, C.K.; Yang, Y.; Li, N.; Shen, L. Wealth, Warmth, and Well-Being: Whether Happiness Is Relative or Absolute Depends on Whether It Is About Money, Acquisition, or Consumption. J. Mark. Res. 2009, 46, 396-409. [CrossRef]

9. Easterlin, R. Does rapid economic growth improve the human lot? Some empirical evidence. Soc. Indic. Res. 1974, 8, 199-221.

10. Easterlin, R. Happiness and Economic Growth: The Evidence; Springer: New York City, NY, USA, 2013.

11. Boffo, M.; Brown, A.; Spencer, D.A. From happiness to social provisioning: Addressing well-being in times of crisis. New Political Econ. 2017, 22, 450-462. [CrossRef]

12. Layard, R. Happiness: Lessons From A New Science; Richard Layard Penguin Press: London, UK, 2005; Volume 84.

13. Austin, A. On Well-Being and Public Policy: Are We Capable of Questioning the Hegemony of Happiness? Soc. Indic. Res. 2016, 127, 123-138. [CrossRef]

14. Sen, A. Development as Freedom; Alfred A Knopf: New York, NY, USA, 1999.

15. Diener, E. Are life satisfaction and happiness the same thing. 2015. Available online: http://internal. psychology.illinois.edu/ \{\}ediener/faq.html\#LS. (accessed on 29 July 2019).

16. Eid, M.; Diener, E. Global Judgments of Subjective Well-Being: Situational Variability and Long-Term Stability. Soc. Indic. Res. 2004, 65, 245-277. [CrossRef]

17. Yang, C.; Srinivasan, P. Life Satisfaction and the Pursuit of Happiness on Twitter. Plos One 2016, 11. [CrossRef]

18. Judge, T.A.; Ilies, R.; Dimotakis, N. Are Health and Happiness the Product of Wisdom? The Relationship of General Mental Ability to Educational and Occupational Attainment, Health, and Well-Being. J. Appl. Psychol. 2010, 95, 454-468. [CrossRef] [PubMed]

19. Kautilya, V. (4th Century). The Arthashastra, Edited, Rearranged, Translated and Introduced by L. N. Rangarajan; Penguin Books: New Delhi, India; New York, NY, USA, 1992.

20. Bascug, E.; Birkenmaier, J. Economic Well-Being in Social Work: New Curricular Resources for Faculty; Council on Social Work Education: Atlanta, GA, USA, 2016.

21. Tranfield, D.; Denyer, D.; Smart, P. Towards a Methodology for Developing Evidence-Informed Management Knowledge by Means of Systematic Review. Br. J. Manag. 2003, 14, 207-222. [CrossRef] 
22. Nofal, A.M.; Nicolaou, N.; Symeonidou, N.; Shane, S. Biology and Management: A Review, Critique, and Research Agenda. J. Manag. 2018, 44, 7-31. [CrossRef]

23. Talan, G.; Sharma, G. Doing Well by Doing Good: A Systematic Review and Research Agenda for Sustainable Investment. Sustainability 2019, 11, 353. [CrossRef]

24. Bansal, S.; Garg, I.; Sharma, G. Social Entrepreneurship as a Path for Social Change and Driver of Sustainable Development: A Systematic Review and Research Agenda. Sustainability 2019, 11, 1091. [CrossRef]

25. Davies, H.; Crombie, I.K. Getting to grips with systematic reviews and meta-analyses. Hosp. Med. 1998, 59, 955-958.

26. Jain, M.; Sharma, G.D. Economics of Happiness-A Systematic Review and Research Agenda. In Proceedings of the British Academy of Management, Bristol, UK, 4-6 September 2018; pp. 1-35.

27. Aghaei Chadegani, A.; Salehi, H.; Md Yunus, M.M.; Farhadi, H.; Fooladi, M.; Farhadi, M.; Ale Ebrahim, N. A comparison between two main academic literature collections: Web of science and scopus databases. Asian Soc. Sci. 2013, 9, 18-26. [CrossRef]

28. Backman, Y. Circles of Happiness: Students' Perceptions of Bidirectional Crossovers of Subjective Well-Being. J. Happiness Stud. 2016, 17, 1547-1563. [CrossRef]

29. Boo, M.C.; Yen, S.H.; Lim, H.E. A Note on Happiness and Life Satisfaction in Malaysia. Malays. J. Econ. Stud. 2016, 53, 261-277.

30. Diener, E. Subjective well-being-The science of happiness and a proposal for a national index. Am. Psychol. 2000, 55, 34-43. [CrossRef]

31. Rothstein, B. Happiness and the welfare state. Soc. Res. Int. Q. 2010, 77, 1-28.

32. Vitterso, J.; Nilsen, F. The conceptual and relational structure of subjective well-being, neuroticism, and extraversion: Once again, neuroticism is the important predictor of happiness. Soc. Indic. Res. 2002, 57, 89-118. [CrossRef]

33. Vermunt, R. Happiness, Well-Being, Satisfaction and Justice as the Concepts of Ultimate-Reality and Meaning Operating in the Science of Social-Psychology. Ultim. Real. Mean. 1989, 12, 272-282. [CrossRef]

34. Ryan, R.M.; Deci, E.L. On happiness and human potentials: A review of research on hedonic and eudaimonic well-being. Annu. Rev. Psychol. 2001, 52, 141-166. [CrossRef]

35. Sousa, R. de Paradoxes of happiness. Dalhous. Rev. 2005, 85, 333-352.

36. Martin, M.W. Paradoxes of happiness. J. Happiness Stud. 2008, 9, 171-184. [CrossRef]

37. Feldman, F. Whole Life Satisfaction Concepts of Happiness. Theor. A Swed. J. Philos. 2008, 74, $219-238$. [CrossRef]

38. Svensson, F. Happiness, Well-being, and Their Relation to Virtue in Descartes' Ethics. Theor. A Swed. J. Philos. 2011, 77, 238-260. [CrossRef]

39. Caunt, B.S.; Franklin, J.; Brodaty, N.E.; Brodaty, H. Exploring the Causes of Subjective Well-Being: A Content Analysis of Peoples' Recipes for Long-Term Happiness. J. Happiness Stud. 2013, 14, 475-499. [CrossRef]

40. Straume, L.V.; Vitterso, J. Happiness, inspiration and the fully functioning person: Separating hedonic and eudaimonic well-being in the workplace. J. Posit. Psychol. 2012, 7, 387-398. [CrossRef]

41. Badhwar, N.K. Well-Being: Happiness in a Worthwhile Life; Oxford University Press: Oxford, UK, 2014; ISBN 978-0-19-532327-6.

42. Lepp, A. Correlating leisure and happiness: The relationship between the leisure experience battery and the Satisfaction With Life Scale. Ann. Leis. Res. 2018, 21, 246-252. [CrossRef]

43. Ryff, C.D. Happiness Is Everything, or Is It-Explorations on the Meaning of Psychological Well-Being. J. Personal. Soc. Psychol. 1989, 57, 1069-1081. [CrossRef]

44. Hosen, R. A Psychology of Happiness and Well-Being and Its Relation to the Psychology of Addiction and Dependence. Psychology 1993, 30, 1-17.

45. Bishop, A.J.; Martin, P.; Poon, L. Happiness and congruence in older adulthood: A structural model of life satisfaction. Aging Ment. Health 2006, 10, 445-453. [CrossRef] [PubMed]

46. Miquelon, P.; Vallerand, R.J. Goal motives, well-being, and physical health: Happiness and self-realization as psychological resources under challenge. Motiv. Emot. 2006, 30, 259-272. [CrossRef]

47. Di Tella, R.; MacCulloch, R. Gross national happiness as an answer to the Easterlin Paradox? J. Dev. Econ. 2008, 86, 22-42. [CrossRef] 
48. Selim, S. Life satisfaction and happiness in Turkey. Soc. Indic. Res. 2008, 88, 531-562. [CrossRef]

49. Siahpush, M.; Spittal, M.; Singh, G.K. Happiness and life satisfaction prospectively predict self-rated health, physical health, and the presence of limiting, long-term health conditions. Am. J. Health Promot. 2008, 23, 18-26. [CrossRef]

50. Linley, P.A.; Maltby, J.; Wood, A.M.; Osborne, G.; Hurling, R. Measuring happiness: The higher order factor structure of subjective and psychological well-being measures. Personal. Individ. Differ. 2009, 47, 878-884. [CrossRef]

51. Simsek, O.F. Happiness Revisited: Ontological Well-Being as a Theory-Based Construct of Subjective Well-Being. J. Happiness Stud. 2009, 10, 505-522. [CrossRef]

52. Spiers, A.; Walker, G.J. The Effects of Ethnicity and Leisure Satisfaction on Happiness, Peacefulness, and Quality of Life. Leis. Sci. 2009, 31, 84-99. [CrossRef]

53. Xiao, J.J.; Tang, C.; Shim, S. Acting for Happiness: Financial Behavior and Life Satisfaction of College Students. Soc. Indic. Res. 2009, 92, 53-68. [CrossRef]

54. Raibley, J.R. Happiness is not Well-Being. J. Happiness Stud. 2012, 13, 1105-1129. [CrossRef]

55. Edouard, R.; Duhaime, G. The Well-Being of the Canadian Arctic Inuit: The Relevant Weight of Economy in the Happiness Equations. Soc. Indic. Res. 2013, 113, 373-392. [CrossRef]

56. Power, M. Well-Being, Quality of Life, and the Naïve Pursuit of Happiness. Topoi 2013, 32, 145-152. [CrossRef]

57. Schütz, E.; Sailer, U.; Al Nima, A.; Rosenberg, P.; Andersson Arntén, A.-C.; Archer, T.; Garcia, D. The affective profiles in the USA: Happiness, depression, life satisfaction, and happiness-increasing strategies. PeerJ 2013, 1, e156. [CrossRef]

58. Ramanathan, S.; O’Brien, C.; Faulkner, G.; Stone, M. Happiness in Motion: Emotions, Well-Being, and Active School Travel. J. Sch. Health 2014, 84, 516-523. [CrossRef]

59. Mujcic, R.; Oswald, A.J. Evolution of Well-Being and Happiness After Increases in Consumption of Fruit and Vegetables. Am. J. Public Health 2016, 106, 1504-1510. [CrossRef]

60. Pandya, S.P. Spirituality, Happiness, and Psychological Well-being in 13- to 15-year olds: A Cross-country Longitudinal RCT Study. J. Pastor. Care Couns. 2017, 71, 12-26. [CrossRef]

61. Ruvolo, A.P. Marital well-being and general happiness of newlywed couples: Relationships across time. J. Soc. Pers. Relatsh. 1998, 15, 470-489. [CrossRef]

62. Rogers, S.J.; DeBoer, D.D. Changes in Wives' Income: Effects on Marital Changes and the Happiness, Psychological Risk of Divorce. J. Marriage Fam. 2001, 63, 458-472. [CrossRef]

63. Roysamb, E.; Tambs, K.; Reichborn-Kjennerud, T.; Neale, M.C.; Harris, J.R. Happiness and Health: Environmental and Genetic Contributions to the Relationship between Subjective Well-Being, Perceived Health, and Somatic Illness. J. Personal. Soc. Psychol. 2003, 85, 1136-1146. [CrossRef] [PubMed]

64. Benjamin, D.J.; Heffetz, O.; Kimball, M.S.; Szembrot, N. Beyond Happiness and Satisfaction: Toward Well-Being Indices Based on Stated Preference. Am. Econ. Rev. 2014, 104, 2698-2735. [CrossRef] [PubMed]

65. Jones, R.C. Migration and Family Happiness in Bolivia: Does Social Disintegration Negate Economic Well-being? Int. Migr. 2014, 52, 177-193. [CrossRef]

66. Schnitzlein, D.D.; Wunder, C. Are We Architects of Our Own Happiness? The Importance of Family Background for Well-Being. B E J. Econ. Anal. Policy 2016, 16, 125-149. [CrossRef]

67. Heizomi, H.; Allahverdipour, H.; Jafarabadi, M.A.; Safaian, A. Happiness and its relation to psychological well-being of adolescents. Asian J. Psychiatry 2015, 16, 55-60. [CrossRef]

68. Bartels, M. Genetics of Wellbeing and Its Components Satisfaction with Life, Happiness, and Quality of Life: A Review and Meta-analysis of Heritability Studies. Behav. Genet. 2015, 45, 137-156. [CrossRef]

69. Kelley, J.; Evans, M.D.R. The new income inequality and well-being paradigm: Inequality has no effect on happiness in rich nations and normal times, varied effects in extraordinary circumstances, increases happiness in poor nations, and interacts with individuals' perceptions, att. Soc. Sci. Res. 2017, 62, 39-74. [CrossRef]

70. Biswas-Diener, R.; Diener, E. The subjective well-being of the homeless, and lessons for happiness. Soc. Indic. Res. 2006, 76, 185-205. [CrossRef] 
71. Leigh, A.; Wolfers, J. Happiness and the human development index: Australia is not a paradox. Aust. Econ. Rev. 2006, 39, 176-184. [CrossRef]

72. Clark, A.E.; Frijters, P.; Shields, M.A. Relative income, happiness, and utility: An explanation for the Easterlin paradox and other puzzles. J. Econ. Lit. 2008, 46, 95-144. [CrossRef]

73. Mahadea, D.; Rawat, T. Economic growth, income and happiness: An exploratory study. South Afr. J. Econ. 2008, 76, 276-290. [CrossRef]

74. Boyce, C.J.; Brown, G.D.A.; Moore, S.C. Money and Happiness: Rank of Income, Not Income, Affects Life Satisfaction. Psychol. Sci. 2010, 21, 471-475. [CrossRef] [PubMed]

75. Delhey, J. From Materialist to Post-Materialist Happiness? National Affluence and Determinants of Life Satisfaction in Cross-National Perspective. Soc. Indic. Res. 2010, 97, 65-84. [CrossRef]

76. Easterlin, R.A.; McVey, L.A.; Switek, M.; Sawangfa, O.; Zweig, J.S. The happiness-income paradox revisited. Proc. Natl. Acad. Sci. Usa 2010, 107, 22463-22468. [CrossRef]

77. Delhey, J.; Kohler, U. Is happiness inequality immune to income inequality? New evidence through instrument-effect-corrected standard deviations. Soc. Sci. Res. 2011, 40, 742-756. [CrossRef]

78. Oishi, S.; Kesebir, S.; Diener, E. Income Inequality and Happiness. Psychol. Sci. 2011, 22, 1095-1100. [CrossRef]

79. Blanchflower, D.G.; Bell, D.N.F.; Montagnoli, A.; Moro, M. The Happiness Trade-Off between Unemployment and Inflation. J. Money Credit. Bank. 2014, 46, 117-141. [CrossRef]

80. Strizovic, I.; Mratinkovic, A. Differences between Employed and Unemployed People in Satisfaction with Life, Subjective Happiness, and Latent and Manifest Benefits of Work. Primenj. Psihol. 2016, 9, 361-377. [CrossRef]

81. Graham, C.; Zhou, S.; Zhang, J. Happiness and Health in China: The Paradox of Progress. World Dev. 2017, 96, 231-244. [CrossRef]

82. Poormahmood, A.; Moayedi, F.; Alizadeh, K.H. Relationships between psychological well-being, happiness and perceived occupational stress among primary school teachers. Arch. Hell. Med. 2017, 34, 504-510.

83. Joo, B.-K.; Lee, I. Workplace happiness: Work engagement, career satisfaction, and subjective well-being. Evid. Based Hrm A Glob. Forum Empir. Scholarsh. 2017, 5, 206-221. [CrossRef]

84. Potapov, D.; Shafranskaya, I.; Bozhya-Volya, A. Happiness and the city An empirical study of the interaction between subjective well-being and city satisfaction. J. Place Manag. Dev. 2016, 9, 313-330. [CrossRef]

85. Ambrey, C.L.; Daniels, P. Happiness and footprints: Assessing the relationship between individual well-being and carbon footprints. Environ. Dev. Sustain. 2017, 19, 895-920. [CrossRef]

86. Radcliff, B. Politics, Markets, and Life Satisfaction: The Political Economy of Human Happiness. Am. Political Sci. Rev. 2001, 95, 939-952. [CrossRef]

87. Gundelach, P.; Kreiner, S. Happiness and life satisfaction in advanced European countries. Cross Cult. Res. 2004, 38, 359-386. [CrossRef]

88. Clapham, D. Happiness, well-being and housing policy. Policy Politics 2010, 38, 253-267. [CrossRef]

89. Kroll, C. Global Development and Happiness: How Can Data on Subjective Well-Being Inform Development Theory and Practice? Oxf. Dev. Stud. 2015, 43, 281-309. [CrossRef]

90. Meier, B.M.; Chakrabarti, A. The paradox of happiness: Health and human rights in the Kingdom of Bhutan. Health Hum. Rights 2016, 18, 193-208.

91. Strotmann, H.; Volkert, J. Multidimensional Poverty Index and Happiness. J. Happiness Stud. 2018, 19, 167-189. [CrossRef]

92. Alessandrini, D.; Jivraj, S. Conceptualising the Economy-Society Nexus in Well-Being and Happiness Initiatives: Gross National Happiness in Business in Bhutan and Social Impact Bonds in the United Kingdom. Int. Crit. Thought 2017, 7, 526-546. [CrossRef]

93. Oishi, S.; Kushlev, K.; Schimmack, U. Progressive Taxation, Income Inequality, and Happiness. Am. Psychol. 2018. [CrossRef] [PubMed]

94. Lewis, C.A.; Joseph, S. Convergent Validity of the Depression-Happiness Scale with Measures of Happiness and Satisfaction with Life. Psychol. Rep. 1995, 76, 876-878. [CrossRef] [PubMed]

95. Hills, P.; Argyle, M. The Oxford Happiness Questionnaire: A compact scale for the measurement of psychological well-being. Personal. Individ. Differ. 2002, 33, 1073-1082. [CrossRef] 
96. Joseph, S.; Linley, P.A.; Harwood, J.; Lewis, C.A.; McCollam, P. Rapid assessment of well-being: The short Depression-Happiness Scale (SDHS). Psychol. Psychother. Theory Res. Pract. 2004, 77, 463-478. [CrossRef] [PubMed]

97. Cox, K. Happiness and Unhappiness in the Developing World: Life Satisfaction Among Sex Workers, Dump-Dwellers, Urban Poor, and Rural Peasants in Nicaragua. J. Happiness Stud. 2012, 13, 103-128. [CrossRef]

98. Weiss, L.A.; Westerhof, G.J.; Bohlmeijer, E.T. Nudging socially isolated people towards well-being with the "Happiness Route": Design of a randomized controlled trial for the evaluation of a happiness-based intervention. Health Qual. Life Outcomes 2013, 11, 1-11. [CrossRef]

99. Santos, M.E. Tracking Poverty Reduction in Bhutan: Income Deprivation Alongside Deprivation in Other Sources of Happiness. Soc. Indic. Res. 2013, 112, 259-290. [CrossRef]

100. Roberts, J.A.; Tsang, J.-A.; Manolis, C. Looking for happiness in all the wrong places: The moderating role of gratitude and affect in the materialism-life satisfaction relationship. J. Posit. Psychol. 2015, 10, 489-498. [CrossRef]

101. Choi, Y.-C.; Jang, J.-H. Relationships Among Social Policy Factors, National Competitiveness, and Happiness. Appl. Res. Qual. Life 2016, 11, 1189-1205. [CrossRef]

102. Joshanloo, M. Mediators of the relationship between externality of happiness and subjective well-being. Personal. Individ. Differ. 2017, 119, 147-151. [CrossRef]

103. Kahneman, D.; Diener, E.; Schwarz, N. Well-being: Foundations of Hedonic Psychology; Russell Sage Foundation: New York, NY, USA, 1999.

104. Waterman, A.S. Two Conceptions of Happiness: Contrasts of Personal Expressiveness (Eudaimonia) and Hedonic Enjoyment. J. Personal. Soc. Psychol. 1993, 64, 678-691. [CrossRef]

105. Hsee, C.K.; Hastie, R.; Chen, J. Hedonomics: Bridging Decision Research With Happiness Research. Perspect. Psychol. Sci. 2008, 3, 224-243. [CrossRef] [PubMed]

106. Mauss, I.B.; Tamir, M.; Anderson, C.L.; Savino, N.S. Can Seeking Happiness Make People Unhappy? Paradoxical Effects of Valuing Happiness. Emotion 2011, 11, 807-815. [CrossRef]

107. Luhmann, M.; Necka, E.A.; Schoenbrodt, F.D.; Hawkley, L.C. Is valuing happiness associated with lower well-being? A factor-level analysis using the Valuing Happiness Scale. J. Res. Personal. 2016, 60, 46-50. [CrossRef]

108. Joshanloo, M.; Rizwan, M.; Khilji, I.A.; Ferreira, M.C.; Poon, W.-C.; Sundaram, S.; Ho, L.S.; Yeung, V.W.; Han, G.; Bae, J.; et al. Conceptions of happiness and life satisfaction: An exploratory study in 14 national groups. Personal. Individ. Differ. 2016, 102, 145-148. [CrossRef]

109. Carlquist, E.; Ulleberg, P.; Delle Fave, A.; Nafstad, H.E.; Blakar, R.M. Everyday Understandings of Happiness, Good Life, and Satisfaction: Three Different Facets of Well-being. Appl. Res. Qual. Life 2017, 12, 481-505. [CrossRef]

110. The Centre for Bhutan Studies and GNH. Happiness: Transforming the Development Landscape; The Centre for Bhutan Studies and GNH: Thimphu, Bhutan, 2017.

111. Veenhoven, R. Social conditions for human happiness: A review of research. Int. J. Psychol. 2015, 50, 379-391. [CrossRef]

112. Chan, C.H.; Wong, H.K.; Yip, P.S.F. Associations of relative income deprivation with perceived happiness and self-rated health among the Hong Kong Chinese population. Int. J. Public Health 2017, 62, 697-707. [CrossRef]

113. Zagorski, K.; Evans, M.D.R.; Kelley, J.; Piotrowska, K. Does National Income Inequality Affect Individuals' Quality of Life in Europe? Inequality, Happiness, Finances, and Health. Soc. Indic. Res. 2014, 117, 1089-1110. [CrossRef]

114. Haybron, D.M. Comments on Badhwar, Well-Being: Happiness in a Worthwhile Life. J. Value Inq. 2016, 50, 195-207. [CrossRef]

115. Badhwar, N.K. Precis of Well-Being: Happiness in a Worthwhile Life. J. Value Inq. 2016, 50, $185-193$. [CrossRef]

116. Snow, N.E. Comments on Badhwar, Well-Being: Happiness in a Worthwhile Life. J. Value Inq. 2016, 50, 209-217. [CrossRef]

117. Hagedorn, J.W. Happiness and Self-Deception: An Old Question Examined by a New Measure of Subjective Well-Being. Soc. Indic. Res. 1996, 38, 139-160. [CrossRef] 
118. Lloyd, K. Happiness and Well-Being of Young Carers: Extent, Nature and Correlates of Caring Among 10 and 11 Year Old School Children. J. Happiness Stud. 2013, 14, 67-80. [CrossRef]

119. Watkins, P.C.; Woddward, K.; Stone, T.; Kolts, R.L. Gratitude and Happiness.Pdf. Soc. Behav. Personal. 2003, 31, 431-452. [CrossRef]

120. Campante, F.; Yanagizawa-Drott, D. Does Religion Affect Economic Growth and Happiness? Evidence from Ramadan. Q. J. Econ. 2015, 130, 615-658. [CrossRef]

121. Banth, S.; Talwar, C. Anasakti, the Hindu Ideal, and its Relationship to Well-Being and Orientations to Happiness. J. Relig. Health 2012, 51, 934-946. [CrossRef]

122. Tsai, M.C.; Qian, Z. Introduction to the Symposium of Manufacturing (Un)Happiness in East Asia: Work, Employment and Well-Being. Soc. Indic. Res. 2015, 121, 1-4. [CrossRef]

123. Joshanloo, M.; Weijers, D. Fear of happiness across cultures: A review of where and why are people afraid of happiness; Victoria University of Wellington: Kelburn, Wellington, 2013.

124. Ferrera, J.M.C.; Salinas-jiménez, J.; Salinas-jiménez, M. Searching for happiness: A cross-national analysis of factors affecting wellbeing using a frontier approach. In XXII Encuentro de Economía Pública: Reformas y nuevos retos de los Estados de Bienestar: eficiencia y equidad (p. 1). 2015. Available online: https://dialnet.unirioja. es/descarga/articulo/5690676.pdf (accessed on 17 December, 2018).

125. Ford, B.Q.; Dmitrieva, J.O.; Heller, D.; Chentsova-Dutton, Y.; Grossmann, I.; Tamir, M.; Uchida, Y.; Koopmann-Holm, B.; Floerke, V.A.; Uhrig, M.; et al. Culture Shapes Whether the Pursuit of Happiness Predicts Higher or Lower Well-Being. J. Exp. Psychol. Gen. 2015, 144, 1053-1062. [CrossRef]

126. Baetschmann, G.; Staub, K.E.; Studer, R. Does the stork deliver happiness? Parenthood and life satisfaction. J. Econ. Behav. Organ. 2016, 130, 242-260. [CrossRef]

127. Lin, J.D.; Lin, P.Y.; Wu, C.L. Wellbeing perception of institutional caregivers working for people with disabilities: Use of Subjective Happiness Scale and Satisfaction with Life Scale analyses. Res. Dev. Disabil. 2010, 31, 1083-1090. [CrossRef] [PubMed]

128. Botha, F.; Booysen, F. Family Functioning and Life Satisfaction and Happiness in South African Households. Soc. Indic. Res. 2014, 119, 163-182. [CrossRef]

129. Kim, J.; Hicks, J.A. Happiness begets children? Evidence for a bi-directional link between well-being and number of children. J. Posit. Psychol. 2016, 11, 62-69. [CrossRef]

130. Dush, C.M.K.; Taylor, M.G.; Kroeger, R.A. Marital happiness and psychological well-being across the life course. Fam. Relat. 2008, 57, 211-226. [CrossRef] [PubMed]

131. Cohn, M.A.; Fredrickson, B.; Brown, S.L.; Conway, A.M.; Mikels, J. A Satisfaction by Building Resilience. Emot. Wash. Dc 2009, 9, 361-368.

132. Sarracino, F. Determinants of Subjective Well-Being in High and Low Income Countries: Do Happiness Equations Differ Across Countries? J. Socio-Econ. 2013, 42, 51-66. [CrossRef]

133. Snow, N.E.; Haq, W.; Ismail, N.A.; Caner, A.; van Praag, B.M.S.; Tsai, M.C.; Qian, Z.; Paul, S.; Guilbert, D.; Kroll, C.; et al. NIH Public Access. Soc. Indic. Res. 2017, 16, 480.

134. Binder, M.; Coad, A. From Average Joe's happiness to Miserable Jane and Cheerful John: Using quantile regressions to analyze the full subjective well-being distribution. J. Econ. Behav. Organ. 2011, 79, $275-290$. [CrossRef]

135. Ngamaba, K.H. Happiness and life satisfaction in Rwanda. J. Psychol. Afr. 2016, 26, 407-414. [CrossRef]

136. Mahadea, D.; Ramroop, S. Influences on Happiness and Subjective Well-Being of Entrepreneurs and Labour: Kwazulu-Natal Case Study. South Afr. J. Econ. Manag. Sci. 2015, 18, 245-259. [CrossRef]

137. Dennis, C.; Alamanos, E.; Papagiannidis, S.; Bourlakis, M. Does social exclusion influence multiple channel use? The interconnections with community, happiness, and well-being. J. Bus. Res. 2016, 69, 1061-1070. [CrossRef]

138. Rakesh Kumar Maurya Physical Facilities and Happiness. Available online: https://rakeshkumarmaurya. wordpress.com/2010/12/26/physical-facilities-and-happiness/ (accessed on 20 April 2019).

139. Oshio, T.; Kobayashi, M. Area-Level Income Inequality and Individual Happiness: Evidence from Japan. J. Happiness Stud. 2011, 12, 633-649. [CrossRef]

140. Lucas, R.E. Adaptation and the set-point model of subjective well-being-Does happiness change after major life events? Curr. Dir. Psychol. Sci. 2007, 16, 75-79. [CrossRef]

141. van Hoorn, A.; Sent, E.-M. Consumer Capital as the Source of Happiness: The Missing Economic Theory Underlying the Income-Happiness Paradox. J. Econ. Issues 2016, 50, 984-1002. [CrossRef] 
142. Li, J. Why Economic Growth did not Translate into Increased Happiness: Preliminary Results of a Multilevel Modeling of Happiness in China. Soc. Indic. Res. 2016, 128, 241-263. [CrossRef]

143. Ruberton, P.M.; Gladstone, J.; Lyubomirsky, S. How Your Bank Balance Buys Happiness: The Importance of "Cash on Hand" to Life Satisfaction. Emotion 2016, 16, 575-580. [CrossRef]

144. Ma, Y.Z.; Zhang, Y. Resolution of the Happiness-Income Paradox. Soc. Indic. Res. 2014, 119, 705-721. [CrossRef]

145. Gatina, L. Does money buy happiness? Financial and general well-being of immigrants in Australia. J. Behav. Exp. Econ. 2016, 63, 91-105. [CrossRef]

146. Oshio, T.; Kobayashi, M. Income inequality, perceived happiness, and self-rated health: Evidence from nationwide surveys in Japan. Soc. Sci. Med. 2010, 70, 1358-1366. [CrossRef]

147. Ayadi, N.; Paraschiv, C.; Vernette, E. Increasing consumer well-being: Risk as potential driver of happiness. Appl. Econ. 2017, 49, 4321-4335. [CrossRef]

148. Tenaglia, S. Testing theories on happiness: A questionnaire. Univ. Tor Vergata-Roma Working Pap. 2007. Available online: https://www.researchgate.net/profile/Simona_Tenaglia/publication/228769946_Testing_ theories_on_happiness_a_questionnaire/links/02bfe50dacd07a8518000000.pdf (accessed on 17 December 2018).

149. Tay, L.; Batz, C.; Parrigon, S.; Kuykendall, L. Debt and Subjective Well-being: The Other Side of the Income-Happiness Coin. J. Happiness Stud. 2017, 18, 903-937. [CrossRef]

150. Welsch, H. Environment and happiness: Valuation of air pollution using life satisfaction data. Ecol. Econ. 2006, 58, 801-813. [CrossRef]

151. Shier, M.L.; Graham, J.R. Subjective well-being, social work, and the environment: The impact of the socio-political context of practice on social worker happiness. J. Soc. Work 2015, 15, 3-23. [CrossRef]

152. Nisbet, E.K.; Zelenski, J.M.; Murphy, S.A. Happiness is in our Nature: Exploring Nature Relatedness as a Contributor to Subjective Well-Being. J. Happiness Stud. 2011, 12, 303-322. [CrossRef]

153. Kuroki, M. Crime Victimization and Subjective Well-Being: Evidence from Happiness Data. J. Happiness Stud. 2013, 14, 783-794. [CrossRef]

154. Veenhoven, R. Happiness in Nations; Snyder, C.R., Lopez, S.J., Edwards, L.M., Marques, S.C., Eds.; 2018; ISBN1 9780199396511. Available online: https://www.oxfordhandbooks.com/view/10.1093/oxfordhb/9780199396511. 001.0001/oxfordhb-9780199396511-e-15 (accessed on 29th July 2019).

155. Fabian, M. Racing from Subjective Well-Being to Public Policy: A Review of The Origins of Happiness: By Andrew E. Clark, Sarah Flèche, Richard Layard, Nattavudh Powdthavee and George Ward. J. Happiness Stud. 2019, 20, 2011-2026. [CrossRef]

156. Pacek, A.; Radcliff, B.; Brockway, M. Well-Being and the Democratic State: How the Public Sector Promotes Human Happiness. Soc. Indic. Res. 2019, 143, 1147-1159. [CrossRef]

157. Loubser, R.; Steenekamp, C. Democracy, well-being, and happiness: A 10-nation study. J. Public Aff. $2017,17$. [CrossRef]

158. Schimmel, J. Development as Happiness: The Subjective Perception of Happiness and UNDP's Analysis of Poverty, Wealth and Development. J. Happiness Stud. 2009, 10, 93-111. [CrossRef]

159. Böckerman, P.; Ilmakunnas, P. Elusive effects of unemployment on happiness. Soc. Indic. Res. 2006, 79, 159-169. [CrossRef]

160. Maennig, W.; Wilhelm, M. Becoming (un)employed and life satisfaction: Asymmetric effects and potential omitted variable bias in empirical happiness studies. Appl. Econ. Lett. 2012, 19, 1719-1722. [CrossRef]

161. Chávez Villegas, C. Happiness and Economic Growth: Lessons from Developing Countries. J. Hum. Dev. Capab. 2016, 17, 296-298. [CrossRef]

162. Paul, S.; Guilbert, D. Income-happiness paradox in Australia: Testing the theories of adaptation and social comparison. Econ. Model. 2013, 30, 900-910. [CrossRef]

163. Clark, A.E.; Fleche, S.; Senik, C. Economic Growth Evens Out Happiness: Evidence from Six Surveys. Rev. Income Wealth 2016, 62, 405-419. [CrossRef] [PubMed]

164. Yu, Z.; Wang, F. Income inequality and happiness: An inverted U-shaped curve. Front. Psychol. 2017, 8, 1-6. [CrossRef] [PubMed]

165. Spruk, R.; Keseljevic, A. Institutional Origins of Subjective Well-Being: Estimating the Effects of Economic Freedom on National Happiness. J. Happiness Stud. 2016, 17, 659-712. [CrossRef] 
166. Adler, A.; Seligman, M.E.P. Using wellbeing for public policy: Theory, measurement, and recommendations. Int. J. Wellbeing 2016, 6, 1-35. [CrossRef]

167. Lucas, R.E.; Donnellan, M.B. How stable is happiness? Using the STARTS model to estimate the stability of life satisfaction. J. Res. Personal. 2007, 41, 1091-1098. [CrossRef]

168. Bond, T.N.; Lang, K. The Sad Truth about Happiness Scales. J. Political Econ. 2019, 127, 1629-1640. [CrossRef]

169. Phelps, C.D. A clue to the paradox of happiness. J. Econ. Behav. Organ. 2001, 45, 293-300. [CrossRef]

170. Ong, Q.; Ho, K.W.; Ho, K.C. Altruism Within the Family: A Comparison of Father and Mother Using Life Happiness and Life Satisfaction. Soc. Indic. Res. 2013, 111, 485-510. [CrossRef]

171. Tsutsui, Y.; Ohtake, F. Asking About Changes in Happiness in a Daily Web Survey and Its Implication for the Easterlin Paradox. Jpn. Econ. Rev. 2012, 63, 38-56. [CrossRef]

172. Proyer, R.T.; Annen, H.; Eggimann, N.; Schneider, A.; Ruch, W. Assessing the "Good Life" in a Military Context: How Does Life and Work-Satisfaction Relate to Orientations to Happiness and Career-Success Among Swiss Professional Officers? Soc. Indic. Res. 2012, 106, 577-590. [CrossRef]

173. Headey, B.; Schupp, J.; Tucci, I.; Wagner, G.G. Authentic happiness theory supported by impact of religion on life satisfaction: A longitudinal analysis with data for Germany. J. Posit. Psychol. 2010, 5, 73-82. [CrossRef]

174. Cheung, F. Can Income Inequality be Associated With Positive Outcomes? Hope Mediates the Positive Inequality-Happiness Link in Rural China. Soc. Psychol. Personal. Sci. 2016, 7, 320-330. [CrossRef]

175. Charman, C.; Owen, A.L. Collective happiness: Labour union membership and life satisfaction. Appl. Econ. Lett. 2014, 21, 924-927. [CrossRef]

176. Piccolo, R.F.; Judge, T.A.; Takahashi, K.; Watanabe, N.; Locke, E.A. Core self-evaluations in Japan: Relative effects on job satisfaction, life satisfaction, and happiness. J. Organ. Behav. 2005, 26, 965-984. [CrossRef]

177. Yang, C. Does Ethical Leadership Lead to Happy Workers? A Study on the Impact of Ethical Leadership, Subjective Well-Being, and Life Happiness in the Chinese Culture. J. Bus. Ethics 2014, 123, 513-525. [CrossRef]

178. Correia, I.; Batista, M.T.; Lima, M.L. Does the belief in a just world bring happiness? Causal relationships among belief in a just world, life satisfaction and mood. Aust. J. Psychol. 2009, 61, 220-227. [CrossRef]

179. Dogan, U. Effects of Social Network Use on Happiness, Psychological Well-being, and Life Satisfaction of High School Students: Case of Facebook and Twitter. Egit. Ve Bilim Educ. Sci. 2016, 41, $217-231$.

180. Rowold, J. Effects of Spiritual Well-Being on Subsequent Happiness, Psychological Well-Being, and Stress. J. Relig. Health 2011, 50, 950-963. [CrossRef] [PubMed]

181. Kushlev, K.; Heintzelman, S.J.; Lutes, L.D.; Wirtz, D.; Oishi, S.; Diener, E. ENHANCE: Design and rationale of a randomized controlled trial for promoting enduring happiness \& well-being. Contemp. Clin. Trials 2017, 52, 62-74. [PubMed]

182. Proyer, R.T.; Ruch, W.; Chen, G.-H. Gelotophobia: Life satisfaction and happiness across cultures. Humor Int. J. Humor Res. 2012, 25, 23-40. [CrossRef]

183. Chui, W.H.; Wong, M.Y.H. Gender Differences in Happiness and Life Satisfaction Among Adolescents in Hong Kong: Relationships and Self-Concept. Soc. Indic. Res. 2016, 125, 1035-1051. [CrossRef]

184. Watkins, P.C.; Woodward, K.; Stone, T.; Kolts, R.L. Gratitude and happiness: Development of a measure of gratitude, and relationships with subjective well-being. Soc. Behav. Personal. 2003, 31, 431-451. [CrossRef]

185. Caner, A. Happiness and Life Satisfaction in Turkey in Recent Years. Soc. Indic. Res. 2016, 127, 361-399. [CrossRef]

186. Shmotkin, D.; Shrira, A. Happiness and Suffering in the Life Story: An Inquiry into Conflicting Expectations Concerning the Association of Perceived Past with Present Subjective Well-Being in Old Age. J. Happiness Stud. 2012, 13, 389-409. [CrossRef]

187. Oishi, S.; Kesebir, S. Income Inequality Explains Why Economic Growth Does Not Always Translate to an Increase in Happiness. Psychol. Sci. 2015, 26, 1630-1638. [CrossRef]

188. Matteson, L.K.; McGue, M.K.; Iacono, W. Is Dispositional Happiness Contagious? The Impact of the Well-Being of Family Members on Individual Well-Being. J. Individ. Differ. 2013, 34, 90-96. [CrossRef]

189. Bojanowska, A.; Zalewska, A.M. Lay Understanding of Happiness and the Experience of Well-Being: Are Some Conceptions of Happiness More Beneficial than Others? J. Happiness Stud. 2016, 17, 793-815. [CrossRef]

190. Kamberi, E.; Martinovic, B.; Verkuyten, M. Life Satisfaction and Happiness Among the Roma in Central and Southeastern Europe. Soc. Indic. Res. 2015, 124, 199-220. [CrossRef] 
191. Caprara, G.V.; Steca, P.; Gerbino, M.; Paciello, M.; Vecchio, G.M. Looking for adolescents' well-being: Self-efficacy beliefs as determinants of positive thinking and happiness. Epidemiol. E Psichiatr. Soc. 2006, 15, 30-43. [CrossRef] [PubMed]

192. Teshale, S.M.; Lachman, M.E. Managing Daily Happiness: The Relationship Between Selection, Optimization, and Compensation Strategies and Well-Being in Adulthood. Psychol. Aging 2016, 31, 687-692. [CrossRef]

193. Vanassche, S.; Swicegood, G.; Matthijs, K. Marriage and Children as a Key to Happiness? Cross-National Differences in the Effects of Marital Status and Children on Well-Being. J. Happiness Stud. 2013, 14, 501-524. [CrossRef]

194. Druzic, M.; Majstorovic, M. Material Well-being and Happiness in Transition Countries. Zagreb Int. Rev. Econ. Bus. 2017, 20, 21-32. [CrossRef]

195. Melzer, S.M.; Muffels, R.J. Migrants' pursuit of happiness: An analysis of the effects of adaptation, social comparison and economic integration on subjective well-being on the basis of German panel data for 1990-2014. Migr. Stud. 2017, 5, 190-215. [CrossRef]

196. Ljunge, M. Migrants, health, and happiness: Evidence that health assessments travel with migrants and predict well-being. Econ. Hum. Biol. 2016, 22, 35-46. [CrossRef]

197. Sarracino, F. Money, Sociability and Happiness: Are Developed Countries Doomed to Social Erosion and Unhappiness? Time-series Analysis of Social Capital and Subjective Well-being in Western Europe, Australia, Canada and Japan. Soc. Indic. Res. 2012, 109, 135-188. [CrossRef]

198. Twenge, J.M.; Sherman, R.A.; Lyubomirsky, S. More Happiness for Young People and Less for Mature Adults: Time Period Differences in Subjective Well-Being in the United States, 1972-2014. Soc. Psychol. Personal. Sci. 2016, 7, 131-141. [CrossRef]

199. Wojcik, S.P.; Ditto, P.H. Motivated Happiness: Self-Enhancement Inflates Self-Reported Subjective Well-Being. Soc. Psychol. Personal. Sci. 2014, 5, 825-834. [CrossRef]

200. Nozaki, K.; Oshio, T. Multidimensional Poverty and Perceived Happiness: Evidence from China, Japan and Korea. Asian Econ. J. 2016, 30, 275-293. [CrossRef]

201. Zuzanek, J.; Zuzanek, T. Of Happiness and of Despair, Is There a Measure? Time Use and Subjective Well-being. J. Happiness Stud. 2015, 16, 839-856. [CrossRef]

202. Powdthavee, N.; Vernoit, J. Parental unemployment and children's happiness: A longitudinal study of young people's well-being in unemployed households. Labour Econ. 2013, 24, 253-263. [CrossRef]

203. Ouyang, Y.; Zhu, Y.; Fan, W.; Tan, Q.; Zhong, Y. People higher in self-control do not necessarily experience more happiness: Regulatory focus also affects subjective well-being. Personal. Individ. Differ. 2015, 86, 406-411. [CrossRef]

204. DeJonge, T.; Veenhoven, R.; Kalmijn, W.; Arends, L. Pooling Time Series Based on Slightly Different Questions About the Same Topic Forty Years of Survey Research on Happiness and Life Satisfaction in The Netherlands. Soc. Indic. Res. 2016, 126, 863-891. [CrossRef]

205. Tesfu, S.T. Poverty, happiness, and risk preferences in rural Ethiopia. Int. J. Happiness Dev. 2017, 3, $342-367$. [CrossRef]

206. Tella, R.D.; MacCulloch, R.J.; Oswald, A.J. Preferences over inflation and unemployment: Evidence from surveys of happiness. Am. Econ. Rev. 2001, 91, 335-341. [CrossRef]

207. Hu, A. Public sector employment, relative deprivation and happiness in adult urban Chinese employees. Health Promot. Int. 2013, 28, 477-486. [CrossRef]

208. Henrich, J.; Boyd, R.; Bowles, S.; Camerer, C.; Fehr, E.; Gintis, H.; Mcelreath, R. American Economic Association In Search of Homo Economicus: Behavioral Experiments in 15 Small-Scale Societies. Am. Econ. Rev. 2001, 91, 73-78. [CrossRef]

209. Heintzelman, S.J.; Diener, E. Subjective well-being, social interpretation, and relationship thriving. J. Res. Personal. 2019, 78, 93-105. [CrossRef]

210. Organisation for Economic Co-operation and Development Guidelines on Measuring Subjective Well-Being. Available online: http://www.oecd.org/statistics/guidelinesonmeasuringsubjectivewell-being.htm (accessed on 30 July 2019).

211. Bhattacharya, S. Relationship between three indices of happiness: Material, mental and spiritual. J. Hum. Values 2010, 16, 87-125. [CrossRef]

212. Bentham, J. An Introduction to the Principles of Morals and Legislation by Jeremy Bentham (1748-1832) 1907 Reprint of 1823 Edition. (First Printed 1780); Clarendon Press: Oxford, UK, 1907. 
213. Wiese, T.R. The cyclical component of GDP and life satisfaction: The impact of the Mediterranean welfare system. Soc. Econ. 2014, 36, 529-542. [CrossRef]

214. Frey, B.S. Happiness: A Revolution in Economics; MIT Press: Cambridge, MA, UK, 2008.

215. Zwolinski, J. Happiness Around the World. In Cross-Cultural Psychology: Contemporary Themes and Perspectives; Keith, K.D., Ed.; John Wiley \& Sons Ltd: Hoboken, NJ, USA, 2019; pp. 531-545.

216. Wiese, T. A literature review of Happiness and Economics and guide to needed research. Competitio 2014, 13, 117-131. [CrossRef]

(C) 2019 by the authors. Licensee MDPI, Basel, Switzerland. This article is an open access article distributed under the terms and conditions of the Creative Commons Attribution (CC BY) license (http://creativecommons.org/licenses/by/4.0/). 